Pacific Northwest National Laboratory

Operated by Battelle for the

U.S. Department of Energy

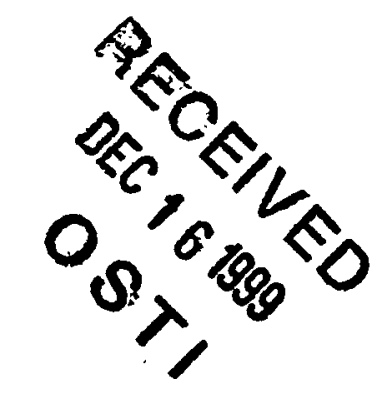

\title{
Hanford Seismic Annual Report and Fourth Quarter Report for Fiscal Year 1999
}

D. C. Hartshorn

S. P. Reidel

A. C. Rohay

December 1999

Prepared for the U.S. Department of Energy under Contract DE-AC06-76RLO 1830 


\section{DISCLAIMER}

This report was prepared as an account of work sponsored by an agency of the United States Government. Reference herein to any specific commercial product, process, or service by trade name, trademark, manufacturer, or otherwise does not necessarily constitute or imply its endorsement, recommendation, or favoring by the United States Government or any agency thereof, or Battelle Memorial Institute.

\section{PACIFIC NORTHWEST NATIONAL LABORATORY operated by BATTELLE for the \\ UNITED STATES DEPARTMENT OF ENERGY under Contract DE-AC06-76RLO 1830}

Printed in the United States of America Available to DOE and DOE contractors from the Office of Scientific and Technical Information; P.O. Box 62, Oak Ridge, TN 37831; prices available from (615) 576-8401.

Available to the public from the National Technical Information Service, U.S. Department of Commerce, 5285 Port Royal Rd., Springfield, VA 22161 


\section{Hanford Seismic Annual Report and Fourth Quarter Report for Fiscal Year 1999}

D. C. Hartshorn

S. P. Reidel

A. C. Rohay

December 1999

Prepared for

the U.S. Department of Energy

under Contract DE-AC06-76RLO 1830

Pacific Northwest National Laboratory

Richland, Washington 99352 


\section{DISCLAIMER}

Portions of this document may be illegible in electronic image products. Images are produced from the best available original document. 


\section{Summary}

Hanford Seismic Monitoring provides an uninterrupted collection of high-quality raw and processed seismic data from the Hanford Seismic Network (HSN) for the U.S. Department of Energy and its contractors. Hanford Seismic Monitoring also locates and identifies sources of seismic activity and monitors changes in the historical pattern of seismic activity at the Hanford Site. The data are compiled, archived, and published for use by the Hanford Site for waste management, Natural Phenomena Hazards assessments, and engineering design and construction. In addition, the seismic monitoring organization works with the Hanford Site Emergency Services Organization to provide assistance in the event of a significant earthquake on the Hanford Site.

The HSN and the Eastern Washington Regional Network.(EWRN) consist of 40 individual sensor sites and 15 radio relay sites maintained by the Hanford Seismic Monitoring staff. A major reconfiguration of the HSN was initiated at the end of this quarter and the results will be reported in the first quarter report for next fiscal year (FY 2000).

For the HSN, there were 390 triggers during the fourth quarter of fiscal year (FY) 1999 on the primary recording system. With the implementation of dual backup systems during the second quarter of the fiscal year and an overall increase observed in sensitivity, a total of 1632 triggers were examined, identified, and processed during this fiscal year.

During the fourth quarter, 24 seismic events were located by the HSN within the reporting region of 46 degrees to 47 degrees north latitude and 119 degrees to 120 degrees west longitude; 9 were earthquakes in the Columbia River Basalt Group, 2 were earthquakes in the pre-basalt sediments, 10 were earthquakes in the crystalline basement, and 2 were quarry blasts. One earthquake appears to be related to a major geologic structure, 14 earthquakes occurred in known swarm areas, and 7 earthquakes were random occurrences.

The HSN was shut down on September 21, 1999 in preparation for moving the central recording site from the $\mathbf{3 0 0}$ Area of the Hanford Site to the Sigma V building in Richland, Washington. Two additional seismic events were detected by the University of Washington network and are included in our analysis. One additional earthquake (for a total of 22 for this quarter), and one additional quarry blast were located in the study region during the fourth quarter.

For the entire fiscal year, 72 earthquakes were located; 39 were earthquakes in the Columbia River Basalt Group, 6 were earthquakes in the pre-basalt sediments, and 27 were earthquakes in the crystalline basement. Geographically, 47 earthquakes occurred in swarm areas, 4 earthquakes were on major structures, and 21 earthquakes were random occurrences.

No earthquakes triggered the Hanford Strong Motion Accelerometers during FY 1999.

A special seismic event was detected and located on August 14, 1999 at 12:00 noon. This unusual event appears to be related to the demolition of towers in the 100-D Area, and includes signals from seismic waves from the explosions, seismic waves from the impact of the towers, and later (delayed) acoustic signals from the explosions. 


\section{Acronyms}

$\begin{array}{ll}\text { BWIP } & \text { Basalt Waste Isolation Project } \\ \text { CRBG } & \text { Columbia River Basalt Group } \\ \text { DMIN } & \text { closest distance from the epicenter to a station } \\ \text { DOE } & \text { U.S. Department of Energy } \\ \text { ETNA } & \text { strong motion accelerometer manufactured by Kinemetrics } \\ \text { EWRN } & \text { Eastern Washington Regional Network } \\ \text { FY } & \text { fiscal year } \\ \text { GAP } & \text { largest gap in event-station azimuth distribution } \\ \text { GPS } & \text { Global Positioning System } \\ \text { HSN } & \text { Hanford Seismic Network } \\ \text { Mc } & \text { Coda Length Magnitude } \\ \text { ML } & \text { Local Magnitude } \\ \text { NP } & \text { number of p-wave and s-wave phases } \\ \text { NS } & \text { number of stations } \\ \text { PNNL } & \text { Pacific Northwest National Laboratory } \\ \text { RAW } & \text { Rattlesnake Mountain-Wallula Alignment } \\ \text { RMS } & \text { root-mean-square residual } \\ \text { SMA } & \text { strong motion accelerometer } \\ \text { USGS } & \text { United States Geological Survey } \\ \text { UTC } & \text { Universal Time, Coordinated } \\ \text { UW } & \text { University of Washington } \\ \text { WHC } & \text { Westinghouse Hanford Company }\end{array}$


. 


\section{Contents}

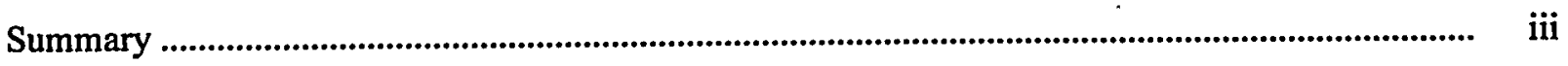

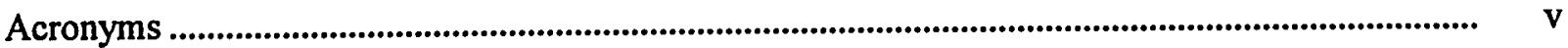

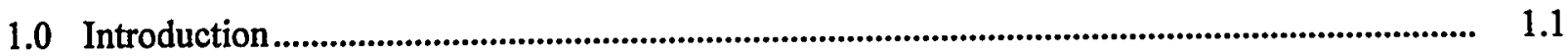

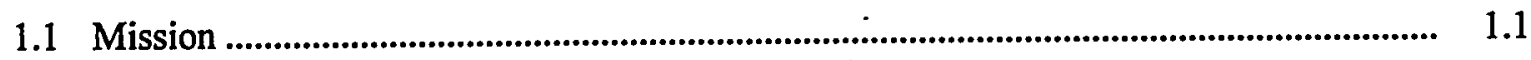

1.2 History of Seismic Monitoring at Hanford ...................................................................... 1.1

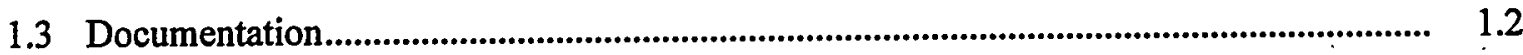

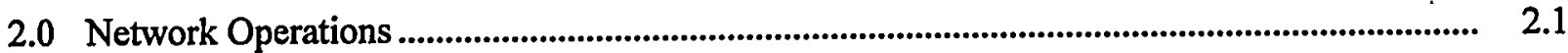

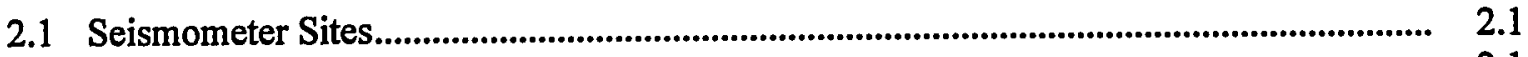

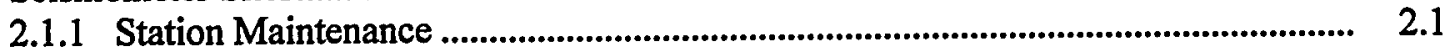

2.1.2 Data Acquisition .......................................................................................... 2.1

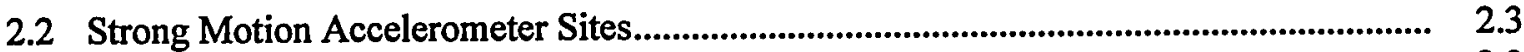

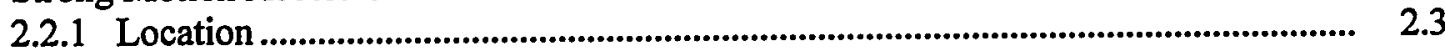

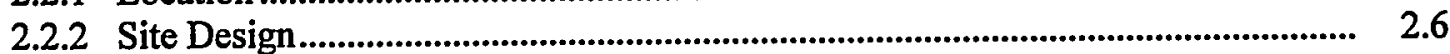

2.2.3 Strong Motion Accelerometer Operations Center ................................................... 2.9

2.2.4 Strong Motion Operational Characteristics ............................................................. 2.9

3.0 Magnitude, Velocity Models, and Quality Factors ........................................................... 3.1

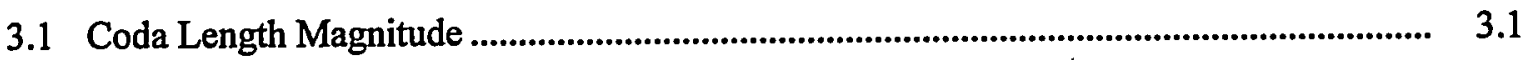

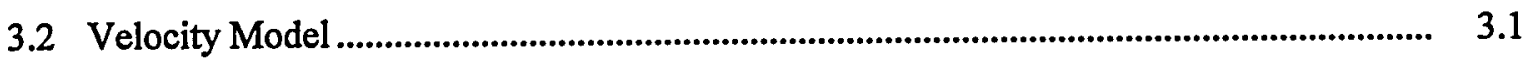

3.3 Quality Factors............................................................................................................... 3.1

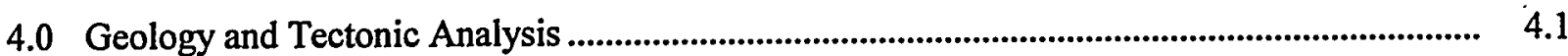

4.1 Earthquake Stratigraphy ................................................................................................. 4.1

4.2 Geologic Structure Beneath the Monitored Area................................................................ 4.1

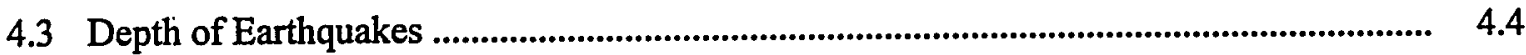

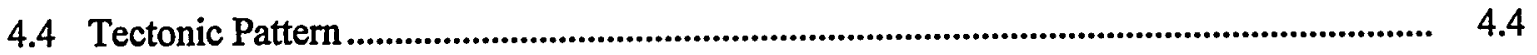

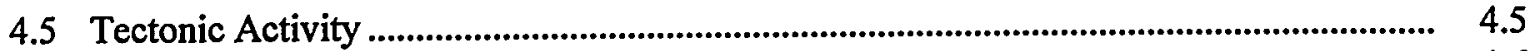

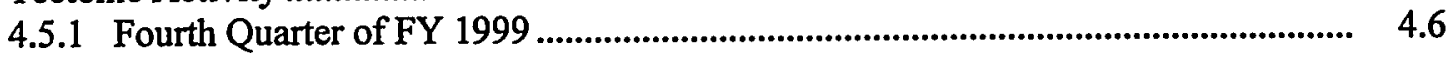

vii 
4.5.2 Major Anticlinal Ridges................................................................................... 4.6

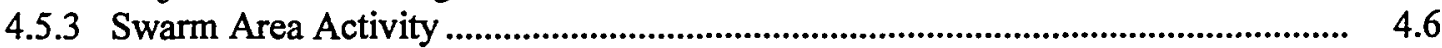

4.5.4 Random or Floating Events ........................................................................... 4.8

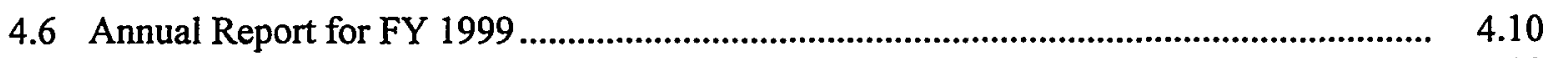

4.6.1 Major Anticlinal Ridges..................................................................................... 4.10

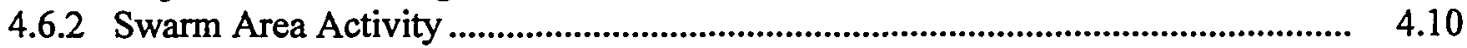

4.6.3 Random or Floating Events .......................................................................... 4.12

5.0 Strong Motion Accelerometer Operations ..................................................................... 5.1

6.0 Capabilities in the Event of a Significant Earthquake............................................................

6.1 Use of the SMA Network in the Event of an Earthquake................................................

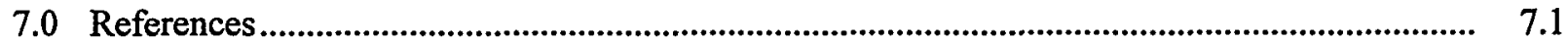




\section{Figures}

2.1 Locations of Seismograph Stations and Strong Motion Accelerometer Sites in the Hanford Seismic Network

2.2 Locations of Seismograph Stations in the Eastern Washington Regional Network

2.3 Schematic Diagram of a Strong Motion Accelerometer Installation

4.1 Structural and Tectonic Map of Columbia Basin Showing Major Seismic Source Structures

4.2 Geologic Cross Sections Through the Columbia Basin

4.3 Locations of all Events Between July 1, 1999 and September 21, 1999

4.4 Locations of all Events that Occurred Between October 1, 1998 and September 21, 1999 ...... 4.9

4.5 Locations of all Events Recorded During FY 1999

\section{Tables}

2.1 Seismic Stations in the Hanford Seismic Network

2.2 Seismic Stations in the Eastern Washington Regional Network................................................ 2.4

2.3 Acquisition System Recorded Triggers

2.6

2.4 Free-Field Strong Motion Accelerometer Sites

2.5 Instrument Parameters for the Kinemetrics ETNA System in the Hanford SMA Network

3.1 Seismic Velocities for Columbia Basin Stratigraphy

3.2 Local Earthquake Data, October 1, 1998 to September 30, 1999

4.1 Thicknesses of Stratigraphic Units Across the Monitoring Area

4.2 Number of Local Earthquakes Occurring in Stratigraphic Units

4.3 Summary of Earthquake Locations 


\subsection{Introduction}

\subsection{Mission}

The principal mission of seismic monitoring at the Hanford Site is to insure compliance with DOE Order 420.1, Facility Safety. This order establishes facility safety requirements related to nuclear safety design, criticality safety, fire protection, and natural phenomena hazards mitigation. With respect to seismic monitoring, the order states:

\subsubsection{Natural Phenomena Detection.}

Facilities or sites with hazardous materials shall have instrumentation or other means to detect and record the occurrence and severity of seismic events.

In addition, seismic monitoring provides an uninterrupted collection of high-quality raw seismic data from the Hanford Seismic Network (HSN) located on and around the Hanford Site, and provides interpretations of seismic events from the Hanford Site and vicinity. Hanford Seismic Monitoring locates and identifies sources of seismic activity, monitors changes in the historical pattern of seismic activity at the Hanford Site, and builds a "local" earthquake database (processed data) that is permanently archived. The focus of this report is the precise location of earthquakes proximal to or on the Hanford Site, specifically between 46 degrees and 47 degrees north latitude and between 119 degrees and 120 degrees west longitude. Data from the Eastern Washington Regional Network (EWRN) and other seismic networks in the northwest provide the Seismic Monitoring Project with necessary regional input for the seismic hazards analysis at the Hanford Site.

The seismic data are used by the Hanford Site contractors for waste management activities, Natural Phenomena Hazards assessments, and engineering design and construction. In addition, the Seismic Monitoring Project works with Hanford Site Emergency Services Organization to provide assistance in the event of an earthquake on the Hanford Site.

\subsection{History of Seismic Monitoring at Hanford}

Seismic monitoring at the Hanford Site was established in 1969 by the United States Geological Survey (USGS) under a contract with the U.S. Atomic Energy Commission. In 1975, the University of Washington (UW) assumed responsibility for the network and subsequently expanded it. In 1979, the Basalt Waste Isolation Project (BWIP) became responsible for collecting seismic data for the Hanford Site as part of site characterization activities. Rockwell Hanford Operations, followed by Westinghouse Hanford Company (WHC), operated the local network and were the contract technical advisors for the EWRN operated and maintained by the UW. Funding ended for BWIP in December 1988. Seismic monitoring and responsibility for the UW contract were then transferred to WHC's Environmental Division. Maintenance responsibilities for the EWRN were also assigned to WHC who made major upgrades to EWRN sites. 
Effective October 1, 1996, seismic monitoring was transferred to the Pacific Northwest National Laboratory (PNNL). ${ }^{1}$ Seismic monitoring is part of PNNL's Applied Geology and Geochemistry Group, Energy Technology Division.

The Hanford Strong Motion Accelerometer (SMA) network was constructed during 1997 and came on line in May 1997. It operated continuously until September 30, 1997 when it was mothballed due to lack of funding. Funding was restored on October 1, 1998 by joint agreement between the U.S. Department of Energy (DOE) and PNNL. Operation of the free-field sites resumed on November 20, 1999.

\subsection{Documentation}

The Seismic Monitoring Project issues quarterly reports of local activity, an annual catalog of earthquake activity on and near the Hanford Site, and special-interest bulletins on local seismic events. The annual catalog includes the fourth quarter report for the fiscal year. Hanford Seismic Monitoring also provides information and special reports to other functions as requested. Earthquake information provided in these reports is subject to revisions if new data become available. In addition, an archive of all seismic data from the HSN is maintained by PNNL.

\footnotetext{
${ }^{1}$ Pacific Northwest National Laboratory is operated by Battelle Memorial Institute for the U.S. Department of Energy.
} 


\subsection{Network Operations}

\subsection{Seismometer Sites}

The seismic monitoring network consists of two designs of equipment and sites: seismometer sites and strong motion accelerometer (SMA) sites. Seismometer sites are designed to locate earthquakes and determine their magnitude and hypocenter location. SMA sites are designed to measure ground motion.

The HSN and the EWRN consists of 40 sensor sites. Most sites are in remote locations and require solar panels and batteries for power. The HSN uses 21 sites (Table 2.1 and Figure 2.1) and the EWRN uses 35 sites (Table 2.2 and Figure 2.2); both networks share 16 sites. The networks have 44 combined data channels because Gable Butte and Frenchman Hills East are three-component sites, each consisting of one vertical, one north-south horizontal, and one east-west horizontal data channel. The Frenchman Hills site is a new site that is under construction and will be operational by the end of the calendar year. Both networks use 15 additional telemetry relay sites. All sites or relays are transmitted to the Sigma V building in Richland, Washington.

During the period of time for this report, all sites and relays were transmitted to the 337 building in the 300 Area of the Hanford Site: This telemetry system used 15 additional relays and a series of telephone datalines. The central recording system was moved to the Sigma V building, in Richland, at the end of fiscal year (FY) 1999, and all sites and relays are now transmitted directly to Sigma V via radio telemetry.

\subsubsection{Station Maintenance}

The HSN's maintenance records for the seismic sensor and relay sites are filed in the Hanford Seismic Monitoring office.

\subsubsection{Data Acquisition}

The signals from the seismometer sites are monitored for changes in signal amplitude that are expected from earthquakes. The seismic network is subdivided into spatial groupings of stations that are monitored for nearly simultaneous amplitude changes, resulting in triggering a permanent recording of the events. The groupings and associated weighting schemes are designed to allow very small seismic events to be recorded and to minimize false triggers. Events are classified as locals (southcentral Washington near the Hanford Site), regionals (Western U.S. and Canada), and teleseisms (from farther distances around the world). Local and regional events are usually earthquakes, but mining explosions are also recorded. The latter can usually be identified from wave characteristics, time of day, and through confirmation with local government agencies and industries. Frequently, military exercises at the Yakima Training Center, northwest of the Hanford Site, produce a series of acoustic shocks that unavoidably trigger the recording system. Sonic booms and thunder also produce acoustic signals that trigger the recording system. 
Table 2.1. Seismic Stations in the Hanford Seismic Network

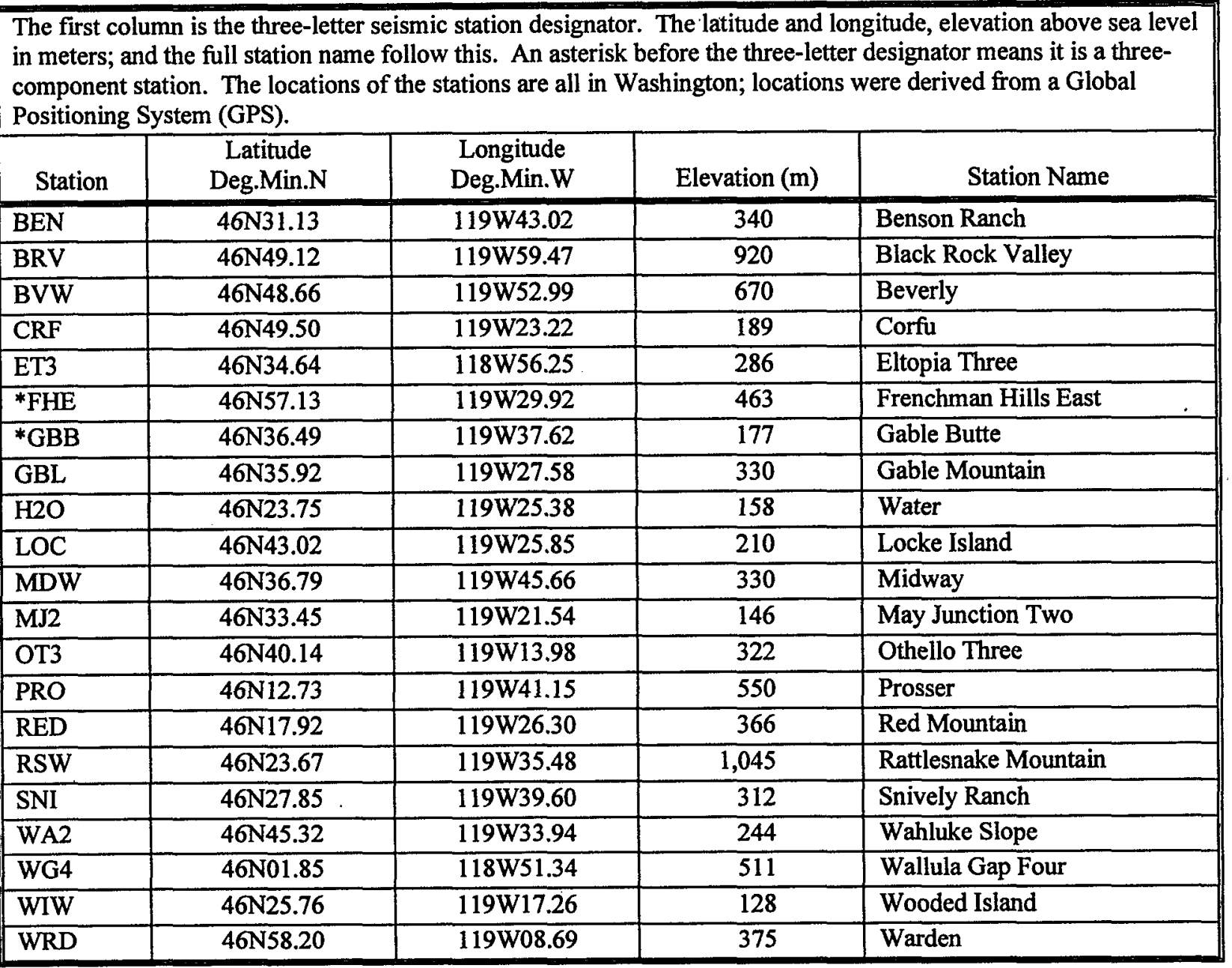

Beginning in the second quarter, there was a significant change in the data acquisition systems. For many years, a single computer system recorded the triggered periods and wrote them to disk. A new PC-based system was adapted from a USGS program and the UW system and was implemented at the Hanford Site. One new system has been in continuous operation since January 6, 1999, initially running concurrently with the old system. The older system irrecoverably failed in early March, so that data could only be recovered through February 10, 1999. A second, backup PC system was installed in mid-March, and both new systems have been running in parallel since that time. Although the two new systems are practically identical, there is enough granularity in the trigger timing that they sometimes record exclusive events. In nearly all cases, these exclusive triggers are "false" triggers, not earthquakes or quarry blasts (i.e., from acoustic sources). The remainder are from barely detectable, small signals from regional and teleseismic earthquakes. By comparing the period from January 6 to February 10, it is clear that the new system is much more sensitive to seismic events and acoustic events than the older system. Some periods of down time have occurred on one or another system, but there were no times of simultaneous down time 


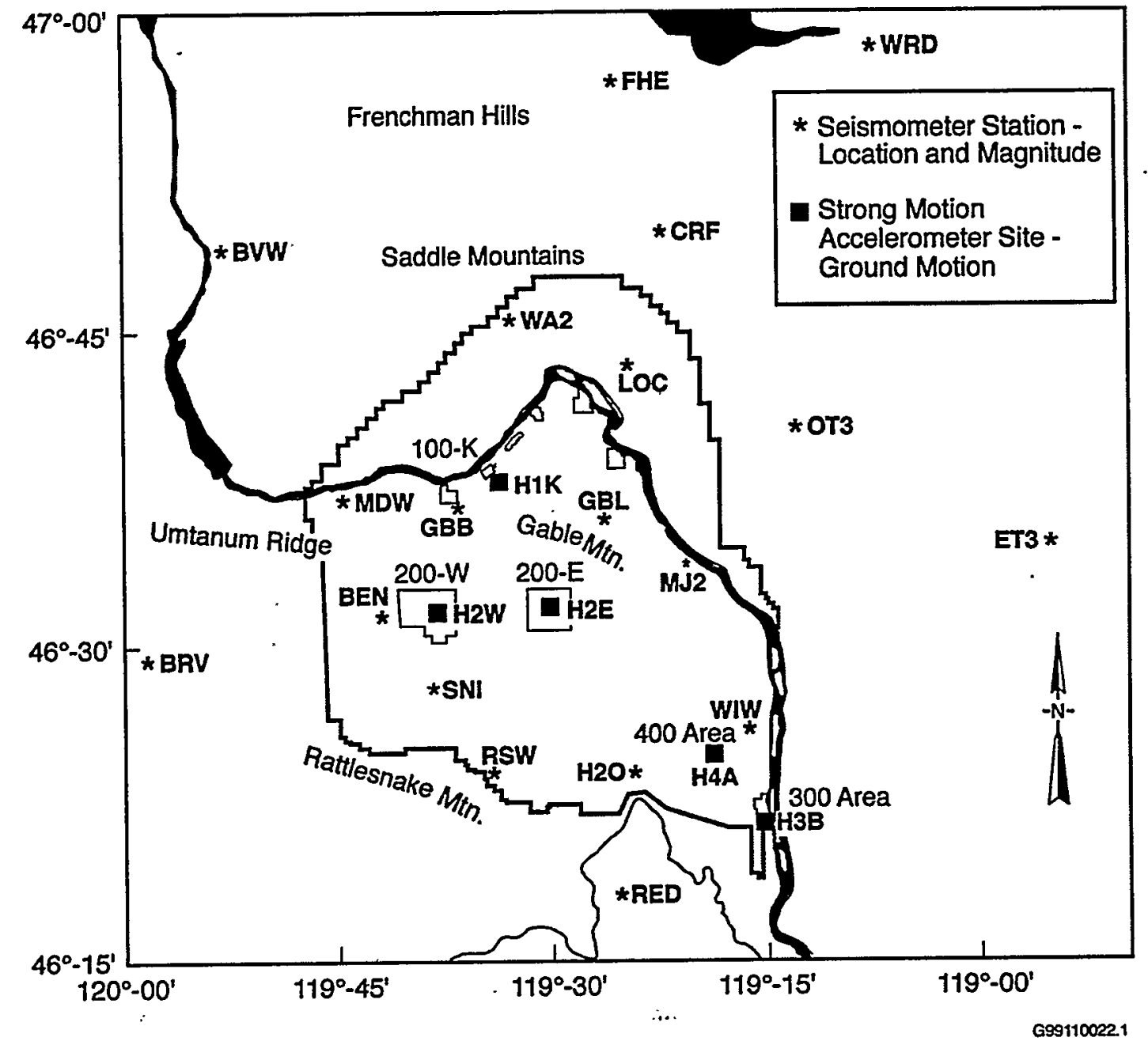

Figure 2.1. Locations of Seismograph Stations and Strong Motion Accelerometer Sites in the Hanford Seismic Network (see Table 2.1 for description of locations) (Prosser and Wallula not shown; see Figure 2.2 for those sites)

except for two events that were detected by the UW during the relocation of the central recording systems to Sigma V at the end of the fiscal year. Table 2.3 shows the number of each type of trigger for each quarter on the two new systems.

\subsection{Strong Motion Accelerometer Sites}

\subsubsection{Location}

The Hanford SMA network consists of five free-field SMA sites (Figure 2.1) (Table 2.4). There is one free-field SMA located in each of the 200 Separations Areas, one adjacent to the K-Basins in 100-K Area, one adjacent to the 400 Area where the Fast Flux Test Reactor is located, and one at the south end of the 300 Area. 
Table 2.2. Seismic Stations in the Eastern Washington Regional Network

\begin{tabular}{|c|c|c|c|c|}
\hline \multicolumn{5}{|c|}{$\begin{array}{l}\text { The first column is the three-letter seismic station designator. The latitude and longitude, elevation above sea level } \\
\text { in meters; and the full station name follow this. An asterisk before the three-letter designator means it is a three- } \\
\text { component station. The locations of the stations are all in Washington unless otherwise indicated; locations were } \\
\text { determined from a Global Positioning System (GPS). }\end{array}$} \\
\hline Station & $\begin{array}{c}\text { Latitude } \\
\text { Deg.Min.N. }\end{array}$ & $\begin{array}{l}\text { Longitude } \\
\text { Deg.Min.W. }\end{array}$ & Elevation (m) & Station Name \\
\hline BRV & $46 \mathrm{~N} 29.12$ & 119W59.47 & 920 & Black Rock Valley \\
\hline BVW & $46 \mathrm{~N} 48.66$ & 119W52.99 & 670 & Beverly Washington \\
\hline CBS & $47 \mathrm{~N} 48.26$ & 120W02.50 & 1,067 & Chelan Butte, South \\
\hline $\mathrm{CRF}$ & $46 N 49.50$ & $119 \mathrm{~W} 23.22$ & 189 & Corfu \\
\hline DPW & $47 \mathrm{~N} 52.25$ & $118 \mathrm{~W} 12.17$ & 892 & Davenport \\
\hline DY2 & 47 N59.11 & $119 W 46.28$ & 890 & Dyer Hill Two \\
\hline ELL & $46 \mathrm{~N} 54.58$ & 120 W33.98 & 789 & Ellensburg \\
\hline EPH & $47 \mathrm{~N} 21.38$ & $119 W 35.76$ & 661 & Ephrata \\
\hline ET3 & 46 N34.64 & 118 W56.25 & 286 & Eltopia Three \\
\hline ETW & $47 \mathrm{~N} 36.26$ & $120 \mathrm{~W} 19.94$ & 1,477 & Entiat \\
\hline *FHE & $46 \mathrm{N57.13}$ & $119 W 29.92$ & 463 & Frenchman Hills East \\
\hline${ }^{*} \mathrm{GBL}$ & $46 \mathrm{~N} 35.92$ & $119 W 27.58$ & 330 & Gable Mountain \\
\hline LNO & $45 \mathrm{~N} 52.31$ & $118 \mathrm{~W} 17.11$ & 771 & Lincton Mountain, Oregon \\
\hline LOC & $46 \mathrm{~N} 43.02$ & $119 \mathrm{~W} 25.85$ & 210 & Locke Island \\
\hline MDW & $4 @ 36.79$ & $119 \mathrm{~W} 45.66$ & 330 & Midway \\
\hline $\mathrm{MJ} 2$ & $46 \mathrm{~N} 33.45$ & 119W21.54 & 146 & May Junction Two \\
\hline MOX & $4 \bigcirc 34.64$ & $120 \mathrm{~W} 17.89$ & 501 & Moxee City \\
\hline NAC & $46 N 43.99$ & 120W49.42 & 728 & Naches \\
\hline NEL & $48 \mathrm{~N} 04.21$ & $120 \mathrm{~W} 20.41$ & 1,500 & Nelson Butte \\
\hline OD2 & $47 \mathrm{~N} 23.26$ & $118 \mathrm{~W} 42.58$ & 553 & Odessa Two \\
\hline OT3 & $46 \mathrm{~N} 40.14$ & $119 \mathrm{~W} 13.98$ & 322 & Othello Three \\
\hline PAT & $45 \mathrm{~N} 52.92$ & $119 \mathrm{~W} 45.14$ & 262 & Paterson \\
\hline PRO & $46 \mathrm{~N} 12.73$ & $119 \mathrm{~W} 41.15$ & 550 & Prosser \\
\hline RSW & $46 \mathrm{~N} 23.67$ & $119 \mathrm{~W} 35.48$ & 1,045 & Rattlesnake Mountain \\
\hline SAW & $47 \mathrm{~N} 42.10$ & $119 \mathrm{~W} 24.03$ & 701 & St. Andrews \\
\hline TBM & $47 \mathrm{~N} 10.20$ & $120 \mathrm{~W} 35.88$ & 1,006 & Table Mountain \\
\hline TRW & $46 \mathrm{~N} 17.32$ & $120 \mathrm{~W} 32.31$ & 723 & Toppenish Ridge \\
\hline TWW & $47 \mathrm{~N} 08.29$ & 120W52.10 & 1,027 & Teanaway \\
\hline VT2 & $46 \mathrm{~N} 58.04$ & 119W58.95 & 1,270 & Vantage Two \\
\hline WA2 & $46 \mathrm{~N} 45.32$ & $119 W 33.94$ & 244 & Wahluke Slope Two \\
\hline WAT & $47 \mathrm{~N} 41.92$ & 119W57.24 & 821 & Waterville \\
\hline WG4 & $46 \mathrm{~N} 01.85$ & 118W51.34 & 511 & Wallula Gap Four \\
\hline WIW & $4 \mathrm{~N} 25.76$ & $119 \mathrm{~W} 17.26$ & 128 & Wooded Island \\
\hline WRD & $46 \mathrm{~N} 58.20$ & 119W08.69 & 375 & Warden \\
\hline YA2 & $46 \mathrm{~N} 31.60$ & $120 \mathrm{~W} 31.80$ & 652 & Yakima Two \\
\hline
\end{tabular}




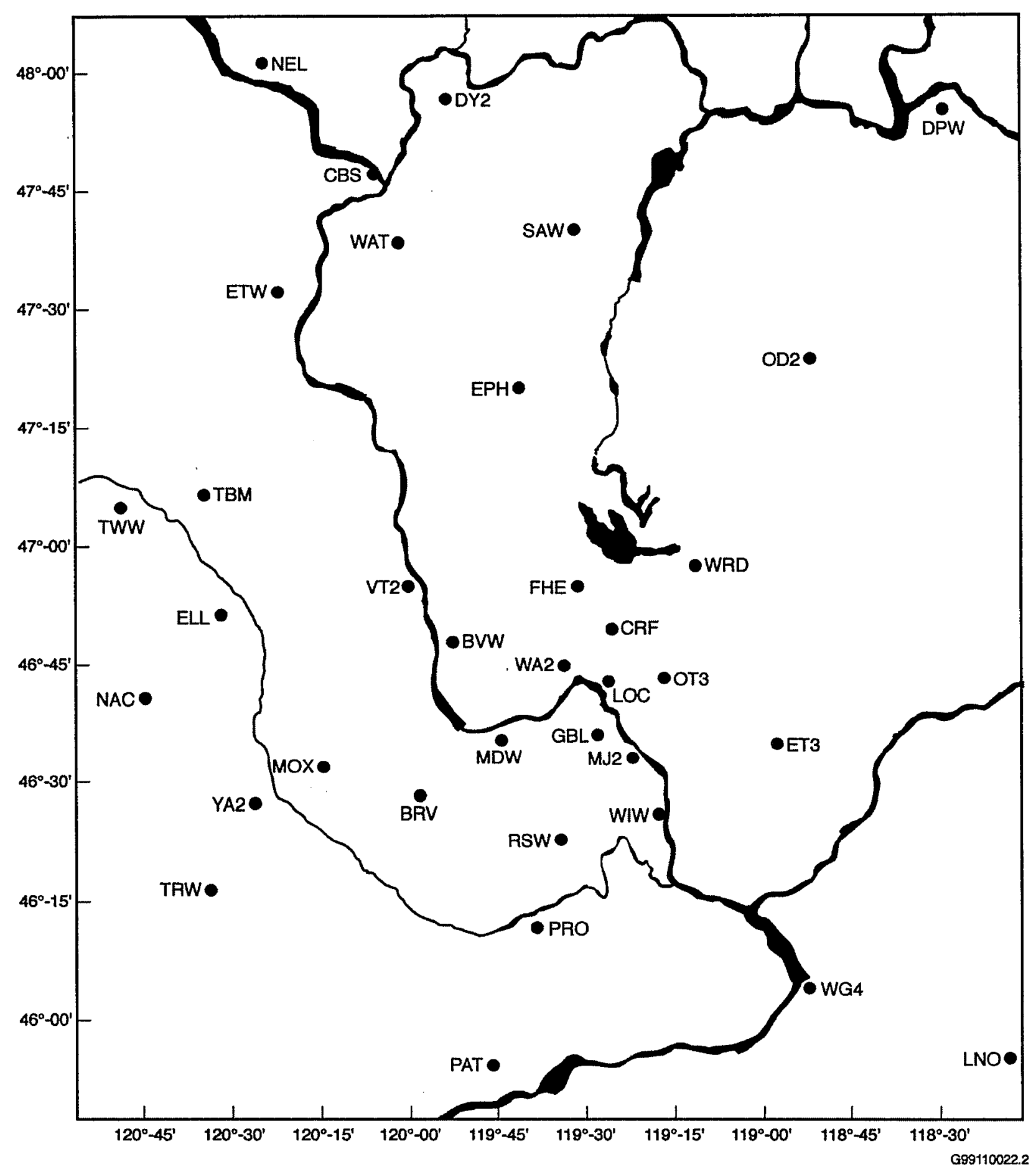

Figure 2.2. Locations of Seismograph Stations in the Eastern Washington Regional Network (see Table 2.2 for location descriptions) 
Table 2.3. Acquisition System Recorded Triggers

\begin{tabular}{|c|c|c|c|c|c|c|c|c|}
\hline \multirow[b]{2}{*}{ Event Type } & \multirow{2}{*}{$\begin{array}{c}\text { First } \\
\text { Quarter }\end{array}$} & \multicolumn{2}{|c|}{$\begin{array}{l}\text { Second } \\
\text { Quarter }\end{array}$} & \multicolumn{2}{|c|}{$\begin{array}{l}\text { Third } \\
\text { Quarter }\end{array}$} & \multicolumn{2}{|c|}{$\begin{array}{l}\text { Fourth } \\
\text { Quarter }\end{array}$} & \multirow[b]{2}{*}{ Remarks } \\
\hline & & $\mathrm{A}$ & B & $\mathrm{A}$ & B & $A$ & B & \\
\hline $\begin{array}{l}\text { Southcentral } \\
\text { Washington }\end{array}$ & $\mathrm{NA}$ & 30 & 7 & 41 & 37 & 38 & 40 & $\begin{array}{l}\text { Seismic events in southcentral Washington and } \\
\text { northcentral Oregon that triggered the HSN }\end{array}$ \\
\hline Regional & 39 & 33 & 3 & 47 & 39 & 39 & 39 & $\begin{array}{l}\text { Seismic events in the Western United States and } \\
\text { Canada }\end{array}$ \\
\hline Teleseism & 43 & 58 & 5 & 73 & 64 & 73 & 65 & $\begin{array}{l}\text { Seismic events at farther distances from around } \\
\text { the world }\end{array}$ \\
\hline Acoustic & 12 & 122 & 33 & 21 & 20 & 53 & 50 & $\begin{array}{l}\text { Acoustical shock waves from artillery, thunder, } \\
\text { and high-performance aircraft sonic booms }\end{array}$ \\
\hline Noise & 10 & 27 & 3 & 47 & 35 & 187 & 182 & $\begin{array}{l}\text { Triggers caused by data line circuits, lightning, } \\
\text { maintenance triggers during system testing, high } \\
\text { winds, coincidental noise at multiple sites within } \\
\text { a trigger subnet, etc. }\end{array}$ \\
\hline \begin{tabular}{|l|} 
Total \\
Triggers \\
\end{tabular} & 121 & 270 & 51 & 229 & 195 & 390 & 376 & A total of 1632 triggers were examined this FY \\
\hline Local & 14 & & & & 3 & $(+2$ & & $\begin{array}{l}\text { Seismic events within the } 46-47 \text { degrees north } \\
\text { latitude and } 119-120 \text { degrees west longitude }\end{array}$ \\
\hline
\end{tabular}

The instrumentation locations were chosen based on two criteria (Moore and Reidel 1996): 1) instruments should be located in areas having the highest densities of people; and 2) instruments should be located in areas having hazardous facilities. Some of the highest concentrations of employees at Hanford are 200 East and West Areas, 100-K Area, the Fast Flux Test Facility (400 Area), and the 300 Areas. The 200 Areas are where all high-level radioactive waste from past processing of fuel rods has been stored in single-shell and double-shell tanks. In addition, the Canister Storage Facility that will hold encapsulated spent fuel rods is being constructed in 200 East Area. The 100-K Area contains the $\mathrm{K}$ Basins where all spent fuel rods from $\mathrm{N}$ Reactor are stored prior to encapsulation. The Cold Vacuum Drying Facility, located in the 100-K Area, will be used to encapsulate spent fuel rods from the $\mathrm{K}$ Basins prior to shipment to the Canister Storage Building in 200 East Area.

\subsubsection{Site Design}

This section describes the designs of the SMA sites as of October 1, 1999. All sites were upgraded during FY 1999 to insure continuous operation and low maintenance.

All free-field SMA sites consist of two 30-gallon drums set in the ground such that the base of the drum is about 1 meter below the surface. One drum houses only the SMA; the other drum houses the electronics and communications equipment. A distance of 1 to $2.16 \mathrm{~m}$ (40 to $85 \mathrm{in}$.) separates the drum containing the electronics and communications equipment from the SMA drum; a sealed conduit connects the two drums. 
Table 2.4. Free-Field Strong Motion Accelerometer Sites

\begin{tabular}{|c|c|c|c|}
\hline Site . & $\begin{array}{l}\text { Site } \\
\text { ID }\end{array}$ & Location. & $\begin{array}{c}\text { Latitude } \\
\text {. Longitude } \\
\text { Elevation }\end{array}$ \\
\hline 100-K Area & H1K & South of K Basins outside 100 Area fence lines. & $\begin{array}{l}46^{\circ} 38.51^{\prime} \\
119^{\circ} 35.53^{\prime} \\
152 \mathrm{~m}\end{array}$ \\
\hline 200 East Area & H2E & $\begin{array}{l}\text { East of B Plant; north of } 7 \text { th street and east of } \\
\text { Baltimore Ave. }\end{array}$ & $\begin{array}{l}46^{\circ} 33.58^{\prime} \\
119^{\circ} 32.00^{\prime} \\
210 \mathrm{~m}\end{array}$ \\
\hline 200 West Area & H2W & $\begin{array}{l}\text { Northeast of Plutonium Finishing Plant (PFP); } \\
\text { north of 19th street and east of Camden Ave. }\end{array}$ & $\begin{array}{l}46^{\circ} 33.23^{\prime} \\
119^{\circ} 37.51^{\prime} \\
206 \mathrm{~m}\end{array}$ \\
\hline 300 Area & $\mathrm{H} 3 \mathrm{~A}$ & $\begin{array}{l}\text { South end of } 300 \text { Area inside fence lines. (NE } \\
1 / 4, \text { SW } 1 / 4, \text { Sec. 11, T10N, R28E). }\end{array}$ & $\begin{array}{l}46^{\circ} 21.83^{\prime} \\
119^{\circ} 16.55^{\prime} \\
119 \mathrm{~m}\end{array}$ \\
\hline 400 Area & H4A & $\begin{array}{l}500 \text { feet from fence line on east side of facility } \\
\text { and north of parking area). }\end{array}$ & $\begin{array}{l}46^{\circ} 26.13^{\prime} \\
119^{\circ} 21.30^{\prime} \\
171 \mathrm{~m}\end{array}$ \\
\hline
\end{tabular}

The SMA instruments are three-component units consisting of one vertical, one north-south horizontal, and one east-west horizontal data channel. The instruments in use are the ETNA ${ }^{\text {TM }}$ system (registered trademark of Kinemetrics, Inc.). Instrument specifications are summarized in Table 2.5. In addition to the three-component SMA's, each ETNA SMA unit contains a computer, Global Positioning System (GPS) receiver, and a modem (Figure 2.3). These systems are housed in a watertight box.

Two 100 amp-hour batteries, housed in the equipment and communications drum (Figure 2.3), power the SMAs. The batteries currently are charged by four solar panels; a regulator is located between the solar panels and the batteries.

The communication link between the SMAs and the data analysis computer system housed in the Sigma $\mathrm{V}$ building is a cellular telephone/modem connection. The built-in modem in the SMA allows the system to use a cellular telephone to call an accelerometer or for the accelerometer to call out in the event it is triggered.

The SMAs have an internal GPS receiver used principally to link it to the National Bureau of Standards timing system. The GPS is internally activated approximately every 4 hours and checks the "location of the instrument" and the time. Any differences between the internal clock and the GPS time are recorded and saved by the SMA. Any corrections to the internal timing are made automatically. After the first 6 months of operation in 1997, the greatest difference recorded is approximately 4 milliseconds. 
Table 2.5. Instrument Parameters for the Kinemetrics ETNA System in the Hanford SMA Network

\begin{tabular}{|c|c|}
\hline Parameter & Value or Range \\
\hline \multicolumn{2}{|l|}{ Sensor } \\
\hline Type & $\begin{array}{l}\text { Tri-axial Force Balance Accelerometer orthogonally } \\
\text { oriented with internal standard }\end{array}$ \\
\hline Full-Scale & $2-2.5 \mathrm{~g}^{(\mathrm{a})}$ \\
\hline Natural Frequency & $50 \pm \mathrm{Hz}$ range \\
\hline Damping & approximately $70 \%$ critical $^{(a)}$ \\
\hline \multicolumn{2}{|l|}{ Data Acquisition } \\
\hline Number of Channels & 3 \\
\hline Sample Rate & 18-bit resolution @ 200 samples/second \\
\hline Digital Output & Real-time, RS-232 Output Stream \\
\hline \multicolumn{2}{|l|}{ Seismic Trigger } \\
\hline Filter & $0.1-12.5 \mathrm{~Hz}$ \\
\hline Trigger level & $0.10 \%-0.20 \% \mathrm{~g}^{(\mathrm{b})}$ \\
\hline Alarm (call-out) Threshold & $4.00 \% \mathrm{~g}$ \\
\hline Pre-event Memory & $10 \mathrm{sec}$ \\
\hline Post-event Time & $40 \mathrm{sec}$ \\
\hline
\end{tabular}

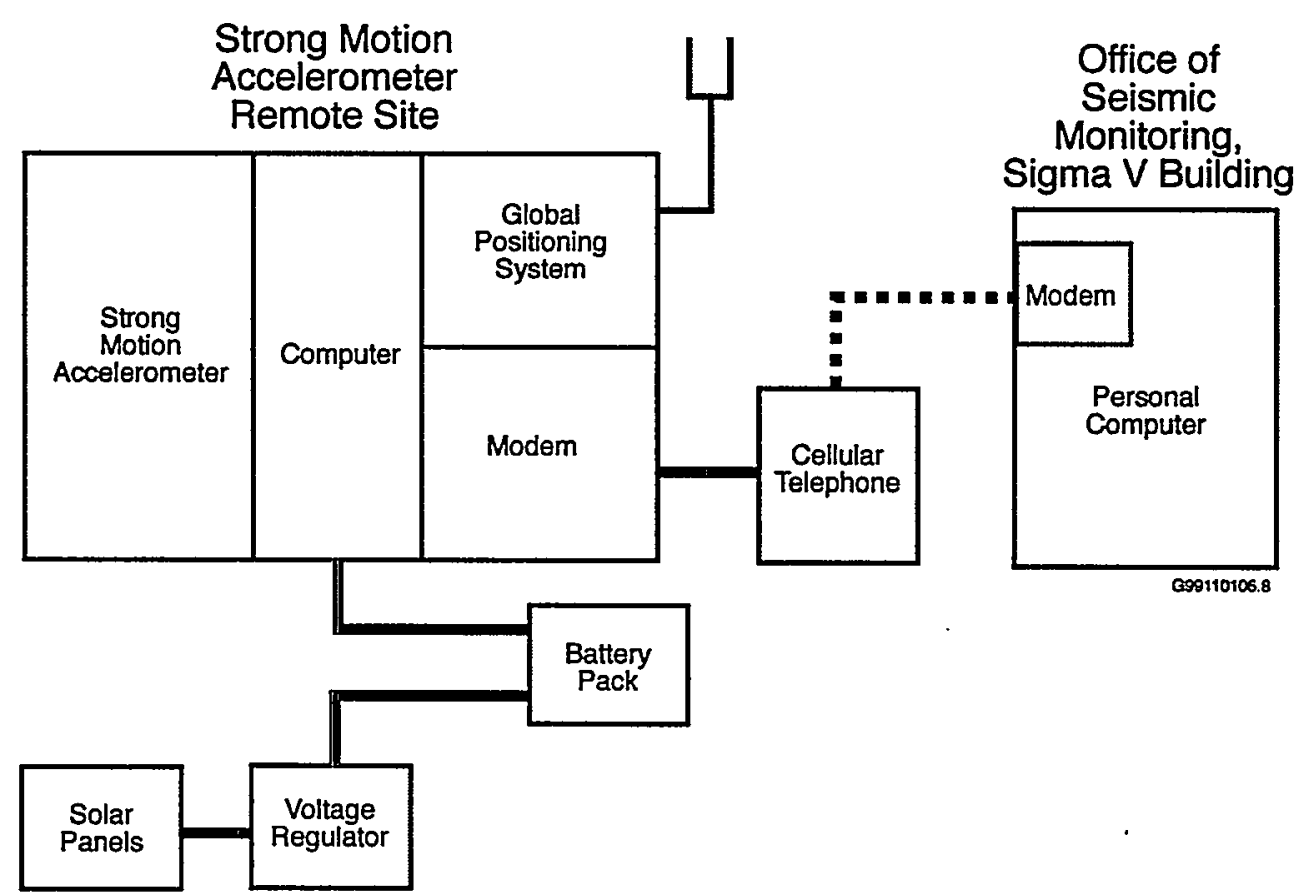

Figure 2.3. Schematic Diagram of a Strong Motion Accelerometer Installation 


\subsubsection{Strong Motion Accelerometer Operations Center}

The combined operations, data recording, data interpretation, and maintenance facility is located in the Sigma V building in Richland, Washington, and is operated by the PNNL Seismic Monitoring Team.

\subsubsection{Strong Motion Operational Characteristics}

The signals from the three accelerometer channels at each site are digitized with a 24-bit digitizer and temporarily stored in a memory buffer. The sampling rate of the digitizer is set to $200 \mathrm{~Hz}$. The three channels are monitored for signals that equal or exceed a programmable trigger threshold. When one accelerometer channel is triggered, the other channels automatically record. The nominal threshold used is $0.05 \%$ of the full-scale range of $2.0 \mathrm{~g}$ ( $\mathrm{g}$ is the acceleration of gravity, $9.8 \mathrm{~m} / \mathrm{s}^{2}$ or $32 \mathrm{ft} / \mathrm{s}^{2}$ ) or $0.001 \mathrm{~g}$. Threshold trigger levels are being adjusted to trigger infrequently on the noise sources (e.g., vehicles, sonic booms) near each site. This will provide ground motion data for smaller, non-damaging earthquakes that can be useful in estimating the ground motion expected from larger earthquakes, and to confirm correct operation of the instruments by analyzing the smaller-amplitude triggers. The recorders store information for 10 seconds before the trigger threshold is exceeded and for 40 seconds after the trigger ceases to be exceeded.

The SMA network is designed to transmit the data to the Hanford Seismic Recording Center at the Sigma $V$ building or to be remotely accessed with a PC and modem. In addition, all SMAs can be accessed in the field where the data can be downloaded and interpreted. 


\subsection{Magnitude, Velocity Models, and Quality Factors}

\subsection{Coda Length Magnitude}

Coda-length magnitude $\left(\mathrm{M}_{c}\right)$, an estimate of local magnitude $\left(\mathrm{M}_{\mathrm{L}}\right)$ (Richter 1958), is calculated using the coda-length/magnitude relationship determined for Washington State by Crosson (1972).

\subsection{Velocity Model}

The program XPED uses the velocities and layer depths given in Table 3.1. XPED was developed at the UW and the velocity model used in XPED is based on Rohay et al. (1985). XPED is an interactive earthquake seismogram display program used to analyze seismic events.

\subsection{Quality Factors (Q)}

XPED assigns a two-letter Quality factor (Table 3.2) that indicates the general reliability of the solution ( $\mathbf{A}$ is best quality, $\mathbf{D}$ is worst). Similar quality factors are used by the USGS for events located with the computer program HYPO71. The first letter of the quality code is a measure of the hypocenter quality based primarily on travel time residuals. For example: Quality A requires a root-mean-square residual (RMS) less than 0.15 seconds while a RMS of 0.5 seconds or more is $\mathbf{D}$ quality (other estimates of the location uncertainty also affect this quality parameter). The second letter of the quality code is related to the spatial distribution of stations that contribute to the event's location, including the number of stations (NS), the number of p-wave and s-wave phases (NP), the largest gap in event-station azimuth distribution (GAP), and the closest distance from the epicenter to a station (DMIN). Quality A requires a solution with NP $>8, \mathbf{G A P}<90^{\circ}$, and DMIN $<5 \mathrm{~km}$ (or the hypocenter depth if it is greater than $5 \mathrm{~km}$ ). If $\mathrm{NP} \leq 5, \mathbf{G A P}>180^{\circ}$, or DMIN $>50 \mathrm{~km}$, the solution is assigned Quality $\mathbf{D}$.

Table 3.1. Seismic Velocities for Columbia Basin Stratigraphy (from Rohay et al. 1985)

\begin{tabular}{||c|l|c|}
\hline $\begin{array}{c}\text { Depth to Top of Velocity } \\
\text { Layer }(\mathrm{km})\end{array}$ & \multicolumn{1}{|c|}{ Stratigraphy } & \multicolumn{1}{|c|}{$\begin{array}{c}\text { Velocity } \\
(\mathrm{km} / \mathrm{sec})\end{array}$} \\
\hline \hline 0.0 & $\begin{array}{l}\text { Saddle Mountains and Wanapum Basalts and intercalated } \\
\text { Ellensburg Formation }\end{array}$ & 3.7 \\
\hline 0.4 & Grande Ronde Basalt and pre-basalt sediments & 5.2 \\
\hline 8.5 & Crystalline Basement, Layer 1 & 6.1 \\
\hline 13.0 & Crystalline Basement, Layer 2 & 6.4 \\
\hline 23.0 & Sub-basement & 7.1 \\
\hline 38.0 & Mantle & 7.9 \\
\hline
\end{tabular}


Table 3.2. Local Earthquake Data, October 1, 1998 to September 30, 1999

\begin{tabular}{|c|c|c|c|c|c|c|c|c|c|c|c|c|c|}
\hline Event ID & Type & Date & Time & Latitude & Longitude & Depth & Mag & NS/NP & Gap & DMIN & RMS & $Q$ & Location \\
\hline 98100916092 & $\mathrm{x}$ & $98 / 10 / 09$ & $16: 09: 26.94$ & $46 \mathrm{~N} 15.16$ & $119 \mathrm{~W} 21.95$ & 0.04 & 2.3 & $14 / 19$ & 217 & 7 & .0 .08 & $\mathrm{AD}$ & $6.7 \mathrm{~km}$ WSW of Richland, WA \\
\hline 98101601453 & & $98 / 10 / 16$ & $01: 47: 42.76$ & $46 \mathrm{~N} 21.14$ & $119 W 23.19$ & 1.61 & 0.1 & $4 / 07$ & 171 & 5 & 0.09 & $\mathrm{AD}$ & $10.5 \mathrm{~km} \mathrm{SSW}$ of 400 Area \\
\hline 98103021542 & & $98 / 10 / 30$ & $21: 54: 21.39$ & $46 \mathrm{~N} 28.19$ & 119W05.34 & 11.61 & 0.6 & $10 / 14$ & 190 & 15 & 0.08 & $\mathrm{AD}$ & $21 \mathrm{~km}$ east of 400 Area \\
\hline 98111623560 & & $98 / 11 / 16$ & $23: 56: 01.77$ & $46 \mathrm{~N} 12.11$ & $119 W 48.35$ & 19.19 & 0.9 & $13 / 18$ & 266 & 27 & 0.06 & $\mathrm{AD}$ & $39 \mathrm{~km} \mathrm{SSW}$ of 200 West Area \\
\hline 98111700013 & & $98 / 11 / 17$ & $00: 01: 33.71$ & $46 \mathrm{~N} 13.27$ & $119 W 47.43$ & 21.49 & 1.2 & $9 / 14$ & 273 & 24 & 0.06 & $\mathrm{AD}$ & $37 \mathrm{~km} \mathrm{SSW}$ of 200 West Area \\
\hline 98111702504 & & $98 / 11 / 17$ & $02: 50: 49.13$ & $46 \mathrm{~N} 09.96$ & $119 W 49.60$ & 17.78 & 1.4 & $15 / 20$ & 275 & 12 & 0.06 & $\mathrm{AD}$ & $43.5 \mathrm{~km}$ of SSW of 200 West Area \\
\hline 98111702561 & & $98 / 11 / 17$ & 02:56:09.49 & $46 \mathrm{~N} 11.21$ & $119 W 47.43$ & 18.19 & 1.0 & $11 / 17$ & 292 & 8 & 0.06 & $\mathrm{AD}$ & $40 \mathrm{~km}$ SSW of 200 West Area \\
\hline 98112203194 & & $98 / 11 / 22$ & $03: 19: 43.49$ & $46 \mathrm{~N} 41.17$ & $119 W 17.22$ & 4.37 & 0.6 & $13 / 19$ & 95 & 4 & 0.04 & $\mathrm{AB}$ & $19 \mathrm{~km}$ east of $100-\mathrm{N}$ Area \\
\hline 98112203344 & & $98 / 11 / 22$ & $03: 34: 46.78$ & $46 \mathrm{~N} 40.96$ & $119 W 17.46$ & 4.62 & 0.8 & $15 / 22$ & 89 & 4 & 0.08 & AA & $20 \mathrm{~km} \mathrm{E}$ of $100-\mathrm{N}$ Area \\
\hline 98112203351 & & $98 / 11 / 22$ & $03: 34: 72.40$ & $46 \mathrm{~N} 41.01$ & $119 W 17.21$ & 3.72 & 0.3 & $14 / 17$ & 137 & 4 & 0.06 & $\mathrm{AC}$ & $21 \mathrm{~km}$ east of $100-\mathrm{N}$ Area \\
\hline 98112203384 & & $98 / 11 / 22$ & 03:38:45.90 & $46 \mathrm{~N} 40.95$ & $119 W 16.81$ & 4.68 & 0.8 & $15 / 21$ & 94 & 3 & 0.08 & $\mathrm{AB}$ & $21 \mathrm{~km}$ east of $100-\mathrm{N}$ Area \\
\hline 98112203392 & & $98 / 11 / 22$ & $03: 38: 84.47$ & $46 \mathrm{~N} 41.34$ & $119 W 16.99$ & 6.61 & -0.6 & $5 / 09$ & 147 & $\overline{4}$ & 0.02 & $\mathrm{AD}$ & $20 \mathrm{~km}$ east of $100-\mathrm{N}$ Area \\
\hline 98112413312 & & $98 / 11 / 24$ & $13: 31: 19.90$ & $46 \mathrm{~N} 13.92$ & $119 W 48.70$ & 12.76 & 0.0 & $4 / 05$ & 329 & 24 & 0.06 & $\mathrm{BD}$ & $36 \mathrm{~km} \mathrm{SSW}$ of 200 West Area \\
\hline 98112518342 & & $98 / 11 / 25$ & $18: 34: 21.75$ & $46 \mathrm{~N} 40.71$ & 23.76 & 24.99 & 0.5 & $5 / 08$ & 262 & 15 & 0.02 & $\mathrm{AD}$ & $12 \mathrm{~km}$ east of $100-\mathrm{N}$ Area \\
\hline 98120312550 & & $98 / 12 / 03$ & 12:55:07.92 & $46 \mathrm{~N} 50.21$ & $119 \mathrm{~W} 17.70$ & 1.57 & 0.9 & $15 / 24$ & 138 & 7 & 0.04 & $\mathrm{AC}$ & $27 \mathrm{~km} \mathrm{NE}$ of $100 \mathrm{~N}$ Area \\
\hline 99010703240 & & $99 / 01 / 07$ & $03: 24: 22.41$ & $46 \mathrm{~N} 29.74$ & $119 \mathrm{~W} 38.50$ & 22.45 & 0.1 & $05 / 06$ & 163 & 11 & 0.03 & $\mathrm{AD}$ & $6.9 \mathrm{~km} \mathrm{~S}$ of 200 West Area \\
\hline 99010709345 & & $99 / 01 / 07$ & $09: 35: 25.08$ & $46 \mathrm{~N} 43.13$ & $119 \mathrm{~W} 30.12$ & 1.50 & 1.6 & $16 / 17$ & 94 & 5 & 0.07 & $\mathrm{AB}$ & $11.2 \mathrm{~km} \mathrm{NE}$ of $100-\mathrm{K}$ Area \\
\hline 99010709371 & & $99 / 01 / 07$ & 09:37:29.10 & $46 \mathrm{~N} 43.58$ & $119 W 29.89$ & 4.01 & 0.9 & $10 / 10$ & 159 & 5 & 0.06 & $\mathrm{AC}$ & $12.1 \mathrm{~km} \mathrm{NE}$ of $100-\mathrm{K}$ Area \\
\hline 99010801025 & & $99 / 01 / 08$ & $01: 03: 19.18$ & $46 \mathrm{~N} 12.00$ & $119 W 27.96$ & 8.81 & 0.8 & $11 / 17$ & 303 & 11 & 0.08 & $\mathrm{AD}$ & $16.3 \mathrm{~km} \mathrm{SW}$ of Richland, WA \\
\hline 99011018163 & & $99 / 01 / 10$ & $18: 16: 58.45$ & $4 \mathrm{~N} 34.57$ & $119 W 22.89$ & 0.29 & 1.4 & $05 / 05$ & 124 & 2 & 0.56 & $\mathrm{DD}$ & $11.9 \mathrm{~km} \mathrm{E}$ of 200 East Area \\
\hline 99011118562 & & $99 / 01 / 11$ & $18: 56: 51.94$ & $4 @ \mathrm{~N} 22.24$ & $119 W 24.93$ & 0.41 & -0.1 & $04 / 06$ & 156 & 2 & 0.26 & $\mathrm{BD}$ & $8.4 \mathrm{~km} \mathrm{SSW}$ of 400 Area \\
\hline 99012502032 & & $99 / 01 / 25$ & $02: 03: 48.51$ & $46 \mathrm{~N} 41.44$ & 119W28.28 & 3.26 & 0.6 & $09 / 13$ & 128 & 4 & 0.06 & $\mathrm{AB}$ & $11.0 \mathrm{~km}$ ENE of $100-\mathrm{K}$ Area \\
\hline 99020407021 & & $99 / 02 / 04$ & $07: 02: 09.55$ & $4 \circlearrowleft \mathrm{N} 28.08$ & $119 \mathrm{~W} 46.16$ & 17.16 & 0.3 & $08 / 13$ & 241 & 6 & 0.05 & $\mathrm{AD}$ & $14.2 \mathrm{~km} \mathrm{SW}$ of 200 West Area \\
\hline
\end{tabular}




\begin{tabular}{|c|c|c|c|c|c|c|c|c|c|c|c|c|c|c|c|c|c|c|c|c|c|c|c|}
\hline 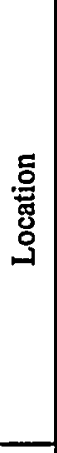 & 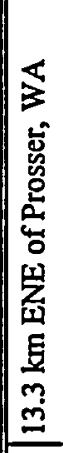 & 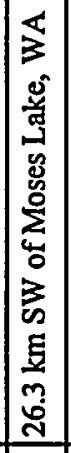 & 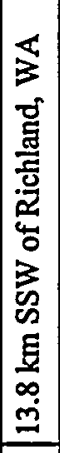 & 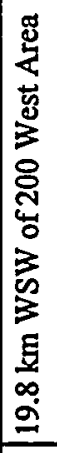 & 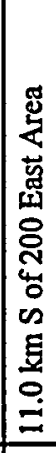 & 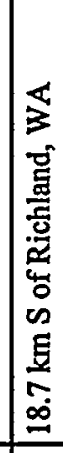 & 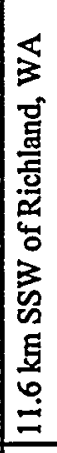 & 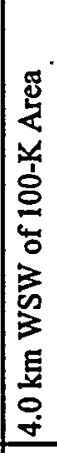 & 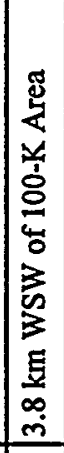 & 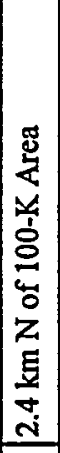 & 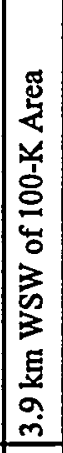 & 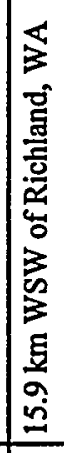 & 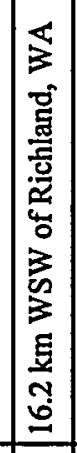 & 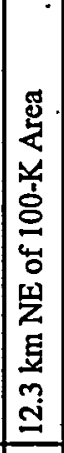 & 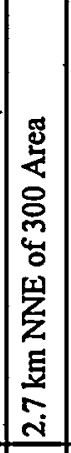 & 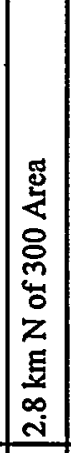 & 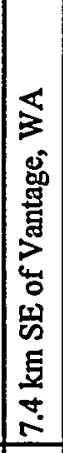 & 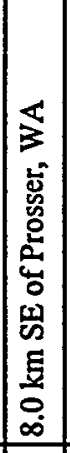 & 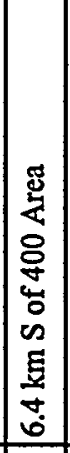 & 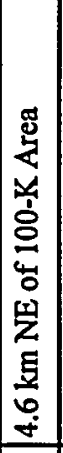 & 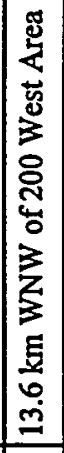 & 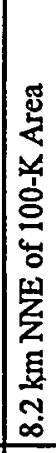 & 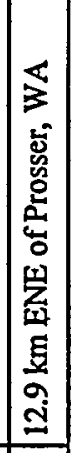 \\
\hline$\alpha$ & U & 是 & 吕 & 舟 & 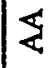 & ठિ & 定 & 里 & $\frac{\xi}{<}$ & $\mathcal{Z}$ & $\frac{9}{2}$ & Q & 早 & 孚 & 是 & 요 & 畐 & 吕 & U & O্口 & 学 & U & 8 \\
\hline$\sum_{\underline{\Omega}}^{\mathscr{L}}$ & $\hat{n}$ & $\frac{m}{0}$ & $\frac{0}{0}$ & 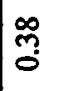 & $\frac{\simeq}{0}$ & ֶֻ. & $\equiv$ & 苂 & $\stackrel{\infty}{\circ}$ & $\frac{m}{0}$ & 总 & $\stackrel{2}{0}$ & gे & 8 & 5 & ণ্ডে & $\frac{9}{0}$ & ণ্ণ & $\stackrel{\overbrace{}}{\sigma}$ & $\frac{=}{0}$ & $\stackrel{\infty}{0}$ & 웅. & है \\
\hline 㤀 & $r$ & 9 & \pm & $\infty$ & 10 & $\vec{\sim}$ & 9 & $N$ & $N$ & 0 & $N$ & 9 & $a$ & + & $n$ & $n$ & $\infty$ & 10 & + & $a$ & $m$ & in & 6 \\
\hline 品 & $\stackrel{n}{s}$ & 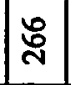 & $\stackrel{m}{g}$ & $\stackrel{8}{\circ}$ & n̊ & 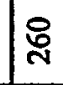 & 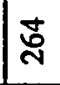 & $\cong$ & in & 8 & 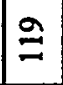 & 兴 & ฟี & $\%$ & $\stackrel{\infty}{\infty}$ & $\widetilde{\infty}$ & 2 & $\frac{m}{m}$ & $\stackrel{\infty}{2}$ & $\tilde{\Xi}$ & ষ্ণি & 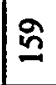 & $\delta$ \\
\hline$\underset{z}{\stackrel{Z}{Z}}$ & $\stackrel{2}{\stackrel{2}{5}}$ & $\bar{\delta}$ & $\bar{B}$ & 疍 & 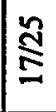 & $\underset{\underset{J}{*}}{\mathbb{Z}}$ & $\frac{5}{5}$ & 옹 & 융 & $\stackrel{\infty}{\$}$ & $\stackrel{m}{\infty}$ & 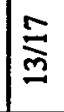 & $\underset{\dot{\phi}}{\bar{\delta}}$ & $\equiv$ & 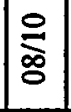 & $\underset{\Sigma}{2}$ & $\stackrel{\infty}{\Sigma}$ & $\underset{5}{\stackrel{5}{5}}$ & $\underset{\stackrel{2}{2}}{\stackrel{2}{2}}$ & $\stackrel{5}{8}$ & $\frac{2}{8}$ & $\stackrel{ }{\circ}$ & $\stackrel{0}{=}$ \\
\hline$\stackrel{\circ}{\mathbb{Z}^{\circ}}$ & $\Xi$ & 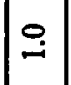 & $\Xi$ & $\dddot{n}$ & 5 & . & $\dddot{2}$ & $\ddot{0}$ & 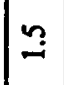 & 5 & $\dddot{n}$ & Y઼ & 3 & 品 & $\stackrel{\circ}{-}$ & $\stackrel{\infty}{-}$ & $\stackrel{i}{\sim}$ & $\stackrel{0}{0}$ & \pm & $\Xi$ & $\infty$ & $\ddot{0}$ & $\stackrel{\text { ì }}{\text { in }}$ \\
\hline $\begin{array}{l}\text { 营 } \\
\text { 口́ }\end{array}$ & $\stackrel{\circ}{\circ}$ & 잉 & 额 & $\stackrel{\substack{m \\
\sim}}{\sim}$ & 资 & $\stackrel{ }{=}$ & 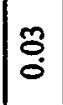 & $\frac{r}{i}$ & 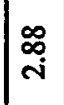 & 5 & ஜֶ. & ๙ૂ & $\underset{\infty}{\mathcal{N}}$ & G్ & ồ & 芯 & $\underset{\mathcal{N}}{\mathcal{N}}$ & 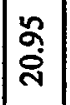 & $\stackrel{P}{0}$ & $\frac{n}{i}$ & $\underset{\infty}{\infty}$ & $\underset{8}{\stackrel{ }{*}}$ & $\boldsymbol{\rho}$ \\
\hline 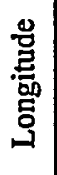 & 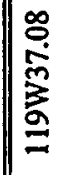 & 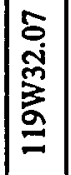 & $\mid \begin{array}{l}\bar{n} \\
\tilde{z} \\
\tilde{z} \\
\vdots\end{array}$ & 㞐 & 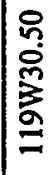 & 突 & 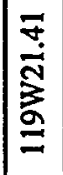 & 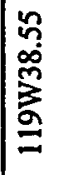 & 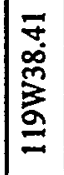 & 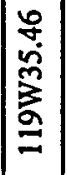 & 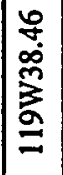 & |ำ & 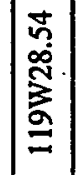 & 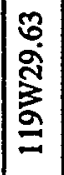 & 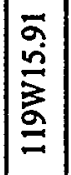 & 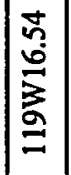 & 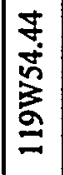 & 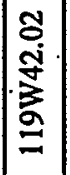 & 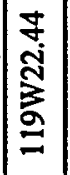 & 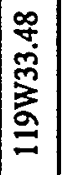 & 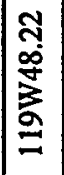 & 今̀ & $1-$ \\
\hline 莡 & $\frac{\stackrel{\varkappa}{a}}{\tilde{z}}$ & 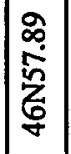 & 号 & $\frac{\bar{z}}{\frac{3}{2}}$ & 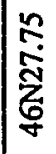 & 容 & 啇 & 孚 & 离 & 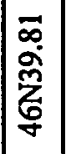 & 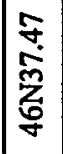 & 导 & $\mid$\begin{tabular}{c}
0 \\
\cline { 1 - 1 } \\
$\frac{3}{6}$
\end{tabular} & 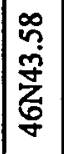 & 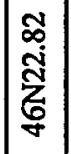 & 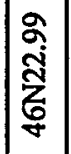 & 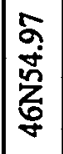 & $\mid \begin{array}{c}\infty \\
\frac{\infty}{8} \\
\stackrel{6}{6}\end{array}$ & 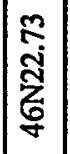 & 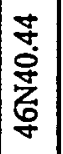 & 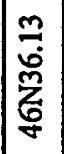 & 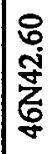 & $\begin{array}{l}\tilde{\infty} \\
\stackrel{m}{m} \\
\stackrel{\vec{z}}{z}\end{array}$ \\
\hline$\underset{E}{\mathscr{E}}$ & 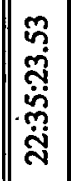 & 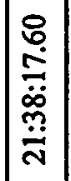 & 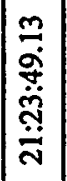 & 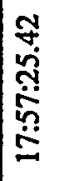 & 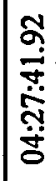 & 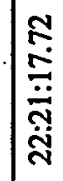 & 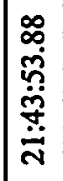 & 㫮 & 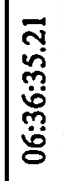 & 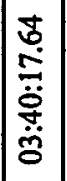 & 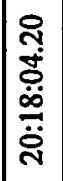 & 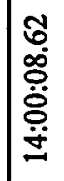 & 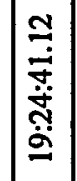 & 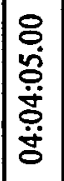 & 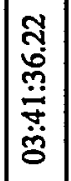 & 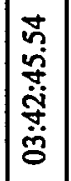 & 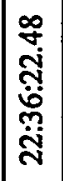 & 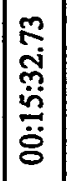 & 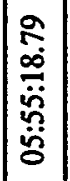 & 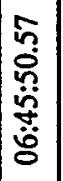 & 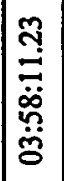 & 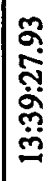 & 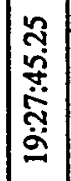 \\
\hline 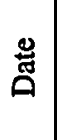 & $\begin{array}{l}\text { ఫ్ } \\
\text { 옹 }\end{array}$ & ষ্ঠু & 공 & 옹 & 융 & 응 & 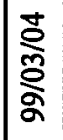 & $\stackrel{\infty}{\stackrel{\infty}{\%}}$ & 종 & 离 & 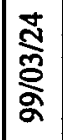 & 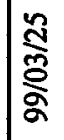 & 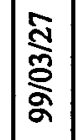 & 誉 & 营 & 志 & $\frac{5}{\frac{5}{5}}$ & 吕 & $\frac{2}{\stackrel{8}{\circ}}$ & $\stackrel{9}{\stackrel{8}{8}}$ & 옹 & 공 & $\stackrel{m}{\stackrel{m}{g}}$ \\
\hline 总 & A & & A & P & & $x$ & $x$ & & & & & & & & & & 4 & $\left.\right|_{0}$ & & & & & a \\
\hline 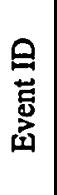 & 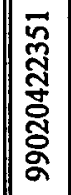 & 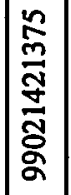 & 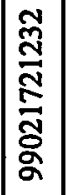 & 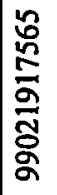 & 공 & 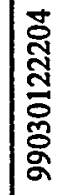 & 总 & 总 & 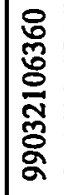 & 总 & 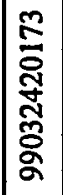 & 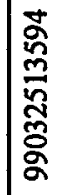 & 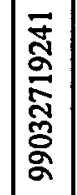 & 芦 & 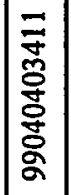 & 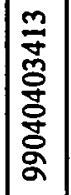 & 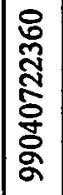 & 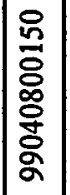 & 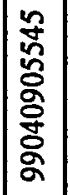 & 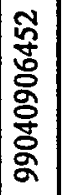 & 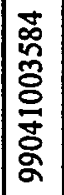 & 总 & 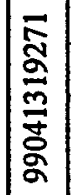 \\
\hline
\end{tabular}


Table 3.2. (contd)

\begin{tabular}{|c|c|c|c|c|c|c|c|c|c|c|c|c|c|}
\hline Event ID & Type & Date & Time & Latitude & Longitude & Depth & Mag & NS/NP & Gap & DMIN & RMS & $\bar{Q}$ & Location \\
\hline 99041501354 & & $99 / 04 / 15$ & $01: 36: 03.10$ & $46 \mathrm{~N} 48.22$ & $119 \mathrm{~W} 42.72$ & 14.09 & 1.0 & $10 / 14$ & 202 & 12 & 0.04 & $\mathrm{AD}$ & $20.0 \mathrm{~km} \mathrm{NNW}$ of $100-\mathrm{K}$ Area \\
\hline 99041716583 & & $99 / 04 / 17$ & $16: 58: 59.22$ & $46 \mathrm{~N} 12.32$ & $119 W 30.50$ & 6.48 & 0.3 & $05 / 07$ & 245 & 11 & 0.12 & $\mathrm{AD}$ & $18.8 \mathrm{~km} \mathrm{WSW}$ of Richland, WA \\
\hline 99041806575 & & $99 / 04 / 18$ & $06: 58: 19.17$ & $46 \mathrm{~N} 48.03$ & 119W33.80 & 15.60 & 0.9 & $10 / 12$ & 222 & 5 & 0.06 & $\mathrm{AD}$ & $17.8 \mathrm{~km} \mathrm{~N}$ of $100-\mathrm{K}$ Area \\
\hline 99042200594 & & $99 / 04 / 22$ & $01: 00: 10.74$ & $46 \mathrm{~N} 22.57$ & $119 W 15.81$ & 0.83 & 0.7 & $05 / 07$ & 254 & 6 & 0.06 & $\mathrm{BD}$ & $2.3 \mathrm{~km} \mathrm{NNE}$ of 300 Area \\
\hline 99042723160 & & $99 / 04 / 27$ & $23: 16: 27.77$ & $46 \mathrm{~N} 27.91$ & $119 W 37.82$ & 17.64 & 0.8 & $09 / 14$ & 107 & 2 & 0.09 & $\mathrm{AB}$ & $10.3 \mathrm{~km} \mathrm{~S}$ of 200 West Area \\
\hline 99051420084 & $\mathbf{P}$ & $99 / 05 / 14$ & $20: 09: 07.18$ & $46 \mathrm{~N} 46.80$ & $119 W 58.36$ & 0.34 & 2.1 & $07 / 07$ & 208 & 7 & 0.20 & $\mathrm{BD}$ & $19.9 \mathrm{~km} \mathrm{~S}$ of Vantage, WA \\
\hline 99051513385 & & $99 / 05 / 15$ & 13:39:17.49 & $46 \mathrm{~N} 48.20$ & 119 W34.18 & 17.01 & 0.4 & $07 / 09$ & 190 & 5 & 0.11 & $\mathrm{AD}$ & $18.1 \mathrm{~km} \mathrm{~N}$ of $100-\mathrm{K}$ Area \\
\hline 99051709541 & & $99 / 05 / 17$ & $09: 54: 40.35$ & $46 \mathrm{~N} 36.24$ & $119 W 47.56$ & 7.78 & 1.5 & $15 / 20$ & 114 & 2 & 0.14 & $\mathrm{AB}$ & $12.9 \mathrm{~km} \mathrm{WNW}$ of 200 West Area \\
\hline 99052401220 & & $99 / 05 / 24$ & $01: 22: 26.46$ & $46 \mathrm{~N} 09.92$ & $119 W 59.80$ & 1.04 & 1.3 & $06 / 06$ & 302 & 24 & 0.18 & $\overline{\mathrm{DD}}$ & $18.3 \mathrm{~km}$ WSW of Prosser, WA \\
\hline 99052401310 & & $99 / 05 / 24$ & $01: 31: 28.86$ & $46 \mathrm{~N} 10.26$ & 119W57.96 & 5.77 & 1.7 & $08 / 08$ & 252 & 22 & 0.07 & BD & $15.8 \mathrm{~km}$ WSW of Prosser, WA \\
\hline 99052420535 & & $99 / 05 / 24$ & $20: 54: 10.96$ & $46 \mathrm{~N} 13.51$ & 119W54.56 & 4.25 & 1.1 & $07 / 07$ & 289 & 17 & 0.01 & $\mathrm{AD}$ & $11.1 \mathrm{~km} \mathrm{~W}$ of Prosser, WA \\
\hline 99060810312 & & $99 / 06 / 08$ & $10: 31: 48.61$ & $46 \mathrm{~N} 05.95$ & 119W58.89 & 8.40 & 1.2 & $05 / 06$ & 322 & 26 & 0.19 & BD & $20.4 \mathrm{~km} \mathrm{SW}$ of Prosser, WA \\
\hline 99060820095 & & $99 / 06 / 08$ & $20: 10: 15.62$ & $46 \mathrm{Ni} 2.16$ & $119 W 58.27$ & 0.41 & 0.8 & $05 / 06$ & 301 & 22 & 0.21 & $\mathrm{CD}$ & $15.7 \mathrm{~km} \mathrm{~W}$ of Prosser, WA \\
\hline 99061314485 & & $99 / 06 / 13$ & $14: 49: 19.04$ & $46 \mathrm{~N} 04.32$ & $119 W 54.70$ & 0.77 & 0.7 & $07 / 09$ & 227 & 23 & 0.08 & $\mathrm{AD}$ & $18.7 \mathrm{~km} \mathrm{SW}$ of Prosser, WA \\
\hline 9907021748 & $\mathbf{P}$ & $99 / 07 / 02$ & 17:48:57.53 & $46 \mathrm{~N} 41.54$ & 119W57.75 & 0.03 & 1.6 & $15 / 16$ & 141 & 14 & 0.24 & $\mathrm{BC}$ & $28.5 \mathrm{~km} \mathrm{WNW}$ of $100-\mathrm{K}$ Area \\
\hline 9907060334 & & 99/07/06 & $03: 34: 23.28$ & $46 \mathrm{~N} 13.41$ & $119 \mathrm{~W} 33.80$ & 17.49 & 0.4 & $10 / 14$ & 290 & 9 & 0.08 & $\mathrm{AD}$ & $15.9 \mathrm{~km} \mathrm{E}$ of Prosser, WA \\
\hline 9907091831 & $\mathbf{P}$ & $99 / 07 / 09$ & $18: 31: 57.94$ & $46 \mathrm{~N} 42.48$ & 119W58.16 & 0.58 & 2.1 & $10 / 10$ & 249 & 13 & 0.15 & $\mathrm{BD}$ & $27.9 \mathrm{~km} \mathrm{~S}$ of Vantage, WA \\
\hline 9907241349 & & $99 / 07 / 24$ & $13: 49: 59.10$ & $46 \mathrm{~N} 48.63$ & 119 W33.11 & 14.85 & 1.3 & $18 / 24$ & 45 & 6 & 0.14 & $\mathrm{AA}$ & $19.1 \mathrm{~km} \mathrm{~N}$ of $100-\mathrm{K}$ Area \\
\hline 9907242202 & & $99 / 07 / 24$ & $22: 03: 13.16$ & $46 \mathrm{~N} 13.12$ & $119 W 44.22$ & 2.20 & 0.6 & $6 / 09$ & 262 & 4 & 0.19 & $\mathrm{BD}$ & $2.7 \mathrm{~km}$ ENE of Prosser, WA \\
\hline 9907300225 & & $99 / 07 / 30$ & $02: 26: 09.63$ & $46 \mathrm{~N} 40.26$ & $119 \mathrm{~W} 36.26$ & 3.28 & -0.1 & $4 / 07$ & 308 & 7 & 0.02 & $\mathrm{AD}$ & $3.3 \mathrm{~km} \mathrm{~N}$ of $100-\mathrm{K}$ Area \\
\hline 9908021513 & & $99 / 08 / 02$ & $15: 13: 54.06$ & $46 \mathrm{~N} 22.83$ & $119 W 15.79$ & 0.18 & 0.7 & $10 / 13$ & 186 & 5 & 0.08 & $\mathrm{AD}$ & $2.8 \mathrm{~km} \mathrm{NNE}$ of 300 Area \\
\hline 9908141700 & $\mathrm{x}$ & $99 / 08 / 14$ & $17: 00: 34.78$ & $46 \mathrm{~N} 41.14$ & $119 W 32.38$ & 0.47 & 1.7 & $8 / 08$ & 101 & 7 & 0.32 & $\mathrm{CB}$ & $6.5 \mathrm{~km} \mathrm{NE}$ of $100-\mathrm{K}$ Area \\
\hline 9908181104 & & $99 / 08 / 18$ & $11: 04: 53.21$ & $46 \mathrm{~N} 44.49$ & 119W35.54 & 1.21 & 1.1 & $11 / 14$ & 191 & 2 & 0.06 & $\mathrm{AD}$ & $11.1 \mathrm{~km} \mathrm{~N}$ of $100-\mathrm{K}$ Area \\
\hline
\end{tabular}


Table 3.2. (contd)

\begin{tabular}{|c|c|c|c|c|c|c|c|c|c|c|c|c|c|}
\hline Event ID & Type & Date & Time & Latitude & Longitude & Depth & Mag & NS/NP & Gap & DMIN & RMS & $Q$ & Location \\
\hline 9908190407 & & $99 / 08 / 19$ & $04: 07: 37.28$ & $46 \mathrm{~N} 30.10$ & $119 W 22.07$ & 2.37 & 0.1 & $6 / 06$ & 204 & 12 & 0.21 & $\mathrm{CD}$ & $7.5 \mathrm{~km} \mathrm{~N}$ of 400 Area \\
\hline 9908261407 & & $99 / 08 / 26$ & $14: 08: 06.83$ & $46 \mathrm{~N} 23.58$ & $119 \mathrm{~W} 35.24$ & 14.77 & 0.4 & $9 / 10$ & 155 & $\overline{0}$ & 0.06 & $\overline{\mathrm{AC}}$ & $18.3 \mathrm{~km}$ WSW of 400 Area \\
\hline 9908291917 & & 99/08/29 & $19: 17: 47.36$ & $46 \mathrm{~N} 36.29$ & $119 \mathrm{~W} 47.76$ & 7.88 & 1.2 & $18 / 20$ & 80 & 2 & 0.11 & $\mathbf{A A}$ & $13.2 \mathrm{~km}$ WNW of 200 West Area \\
\hline 9908291946 & & $99 / 08 / 29$ & $19: 47: 01.95$ & $46 \mathrm{~N} 23.45$ & $119 \mathrm{~W} 14,18$ & 5.66 & 0.7 & $8 / 12$ & 263 & 5 & 0.22 & BD & $4.9 \mathrm{~km} \mathrm{NE}$ of 300 Area \\
\hline 9908301514 & & $99 / 08 / 30$ & $15: 14: 44.72$ & $46 \mathrm{~N} 22.88$ & $119 \mathrm{~W} 15.81$ & 1.85 & 0.5 & $7 / 08$ & 254 & 5 & 0.12 & $\mathrm{BD}$ & $2.8 \mathrm{~km} \mathrm{NNE}$ of 300 Area \\
\hline 9909010024 & & $99 / 09 / 01$ & $00: 24: 36.74$ & $46 \mathrm{~N} 22.01$ & $119 W 06.66$ & 0.02 & 0.2 & $6 / 09$ & 299 & 15 & 0.15 & $\mathrm{BD}$ & $12.9 \mathrm{~km} \mathrm{E}$ of 300 Area \\
\hline 9909052010 & & $99 / 09 / 05$ & $20: 10: 58.35$ & $46 \mathrm{~N} 12.48$ & $119 \mathrm{~W} 25.54$ & 9.44 & 0.3 & $8 / 12$ & 303 & 9 & 0.15 & $\mathrm{BD}$ & $13.3 \mathrm{~km} \mathrm{SW}$ of Richland, WA \\
\hline 9909061253 & & $99 / 09 / 06$ & $12: 54: 10.55$ & $46 \mathrm{~N} 04.47$ & 119 W52.23 & 0.72 & 0.3 & $5 / 09$ & 320 & 20 & 0.33 & $\mathrm{CD}$ & $16.7 \mathrm{~km}$ SSW of Prosser, WA \\
\hline 9909110217 & & $99 / 09 / 11$ & $02: 18: 12.46$ & $46 \mathrm{~N} 27.11$ & 119W37.91 & 17.28 & 0.1 & $9 / 13$ & 148 & 2 & 0.08 & $\mathrm{AC}$ & $11.8 \mathrm{~km} \mathrm{~S}$ of 200 West Area \\
\hline 9909132125 & & $99 / 09 / 13$ & $21: 25: 52.47$ & $46 \mathrm{~N} 23.92$ & $119 W 57.98$ & 13.58 & -0.3 & $3 / 05$ & 335 & 23 & 0.15 & $\mathrm{CD}$ & $26.2 \mathrm{~km} \mathrm{NW}$ of Prosser, WA \\
\hline 9909172246 & 7 & $99 / 09 / 17$ & $22: 47: 14.32$ & $46 \mathrm{~N} 50.76$ & $119 \mathrm{~W} 31.08$ & 0.78 & 1.4 & $12 / 12$ & 122 & 10 & 0.04 & $\mathrm{AC}$ & $23.5 \mathrm{~km} \mathrm{NNE}$ of $100-\mathrm{K}$ Area \\
\hline 9909190421 & & $99 / 09 / 19$ & $04: 21: 44.38$ & $46 \mathrm{~N} 26.52$ & $119 W 37.88$ & 20.32 & 3.0 & $28 / 28$ & 88 & 3 & 0.19 & $\mathrm{BA}$ & $12.9 \mathrm{~km} \mathrm{~S}$ of 200 West Area \\
\hline 9909190507 & & $99 / 09 / 19$ & $05: 07: 56.42$ & $46 \mathrm{~N} 26.96$ & 119 W 37.48 & 15.14 & 0.4 & $9 / 12$ & 144 & 3 & 0.06 & $\mathrm{AC}$ & $12.1 \mathrm{~km} \mathrm{~S}$ of 200 West Area \\
\hline 9909192333 & & $99 / 09 / 19$ & $23: 34: 25.93$ & $46 \mathrm{~N} 26.57$ & 119 W38.04 & 17.22 & 1.4 & $20 / 22$ & 88 & 3 & 0.12 & $\overline{\mathrm{AA}}$ & $12.8 \mathrm{~km} \mathrm{~S}$ of 200 West Area \\
\hline 9909202225 & & $99 / 09 / 20$ & $22: 26: 02.58$ & $46 \mathrm{~N} 27.24$ & $119 W 35.74$ & 16.90 & -0.1 & $10 / 13$ & 105 & 5 & 0.04 & $\overline{\mathrm{AB}}$ & $12.0 \mathrm{~km}$ SSE of 200 West Area \\
\hline 9909212030 & $P$ & $99 / 09 / 21$ & $20: 30: 31.59$ & $46 \mathrm{~N} 12.40$ & 119 W35.19 & $0.03^{*}$ & 1.5 & $5 / 005$ & 188 & 7 & 0.79 & $\mathrm{DD}$ & $14.0 \mathrm{~km} \mathrm{E}$ of Prosser, WA \\
\hline 9909271455 & & $99 / 09 / 27$ & $14: 55: 49.35$ & $46 \mathrm{~N} 26.90$ & $119 \mathrm{~W} 38.05$ & 15.77 & 1.0 & $9 / 012$ & 127 & 6 & 0.09 & $\overline{\mathrm{AB}}$ & $28.8 \mathrm{~km}$ NNE of Prosser, WA \\
\hline
\end{tabular}




\section{Explanation of Table 3.2}

EVENT ID: The Earthworm Recording System creates the identification number. XPED uses the year, month, day and time to create a unique number for each event.

TYPE: $\quad P$ is Probable Blast; $\mathrm{X}$ is Confirmed Blast; $\mathrm{F}$ is Felt Earthquake; $\mathrm{H}$ is hand picked from helicorder; $\mathrm{S}$ is surficial event (rockslide, avalanche) and not a explosion or tectonic earthquake; blank is local earthquake.

DATE: $\quad$ The year and day of the year in Universal Time Coordinated (UTC). UTC is used throughout this report unless otherwise indicated.

TIME: The origin time of the earthquake given in UTC. To covert UTC to Pacific Standard Time, subtract eight hours; to Pacific Daylight Time, subtract seven hours.

LATITUDE: North latitude, in degrees and minutes, of the earthquake epicenter.

LONGITUDE: West longitude, in degrees and minutes, of the earthquake epicenter.

DEPTH: $\quad$ The depth of the earthquake in kilometers $(\mathrm{km})$.

MAG: $\quad$ The magnitude is expressed as Coda-Length magnitude $\mathrm{M}_{\mathrm{c}}$, an estimate of local magnitude $\mathrm{M}_{\mathrm{L}}$ (Richter 1958). If Magnitude is blank no determination could be made.

NS/NP: $\quad$ Number of stations/number of phases used in the solutions.

GAP: $\quad$ Azimuthal gap. The largest angle (relative to the epicenter) containing no stations.

DMIN: The distance from the earthquake epicenter to the closest station

RMS: $\quad$ The root-mean-square residual (observed arrival times minus the predicted arrival times) at all stations used to locate the earthquake. It is only useful as a measure of quality of the solution when five or more well-distributed stations are used in the solution. Good solutions are normally characterized by RMS values of less than about 0.3 seconds.

Q: - The Quality Factors indicate the general reliability of the solution/location (A is best quality, D is worst). See Section 3.3 of this report: Quality Factors. 


\subsection{Geology and Tectonic Analysis}

The Hanford Site lies within the Columbia Basin, which is an intermontane basin between the Cascade Range and the Rocky Mountains that is filled with Cenozoic volcanic rocks and sediments. This basin forms the northern part of the Columbia Plateau physiographic province (Fenneman 1931) and the Columbia River flood-basalt province (Reidel and Hooper 1989). In the central and western parts of the Columbia Basin, the CRBG overlies Tertiary continental sedimentary rocks and is overlain by late Tertiary and Quaternary fluvial and glaciofluvial deposits (Campbell 1989; Reidel and others 1989; DOE 1988). In the eastern part, a thin $(<100 \mathrm{~m})$ sedimentary unit separates the basalt and underling crystalline basement and a thin $(<10 \mathrm{~m})$ veneer of eolian sediments overlies the basalt (Reidel and others 1989).

The Columbia Basin has two structural subdivisions or subprovinces: the Yakima Fold Belt and the Palouse Slope. The Yakima Fold Belt includes the western and central parts of the Columbia Basin and is a series of anticlinal ridges and synclinal valleys with major thrust faults along the northern flanks (Figure 4.1). The Palouse Slope is the eastern part of the basin and is the least deformed subprovince with only a few faults and low amplitude, long wavelength folds on an otherwise gently westward dipping paleoslope. Figure 4.2 shows north-south and east-west cross sections through the Columbia Basin based on surface mapping, deep boreholes, geophysical data (including the work of Rohay et al. [1985]), and magnetotelluric data obtained as part of BWIP (DOE 1988).

\subsection{Earthquake Stratigraphy}

Studies of seismicity at the Hanford Site have shown that the seismicity is related to crustal stratigraphy (layers of rock types) (Rohay et al. 1985; DOE 1988). The main geologic units important to earthquakes at Hanford and the surrounding area are:

- The Miocene CRBG

- The Paleocene, Eocene, and Oligocene sediments

- The crystalline basement (Precambrian and Paleozoic craton; Mesozoic accreted terranes).

\subsection{Geologic Structure Beneath the Monitored Area}

Between the late 1950s and the early 1980s, deep boreholes were drilled for hydrocarbon exploration in the Columbia Basin. These boreholes provided accurate measurements of the physical properties of the CRBG and the pre-basalt sediments (Reidel et al. 1994, 1998), but the thickness of the pre-basalt sediments and nature of the crystalline basement are still poorly understood. The difference between the thicknesses listed in Table 4.1 and the thicknesses of the crustal layers in the velocity model in Table 3.1 reflect data specific to the UW's crustal velocity model for eastern Washington. Table 4.2 is derived from Figure 4.2 and was developed for the geologic interpretation in this report. The thicknesses of these units are variable across the monitored area. Table 4.1 summarizes the approximate thickness at the borders of the monitored area. 


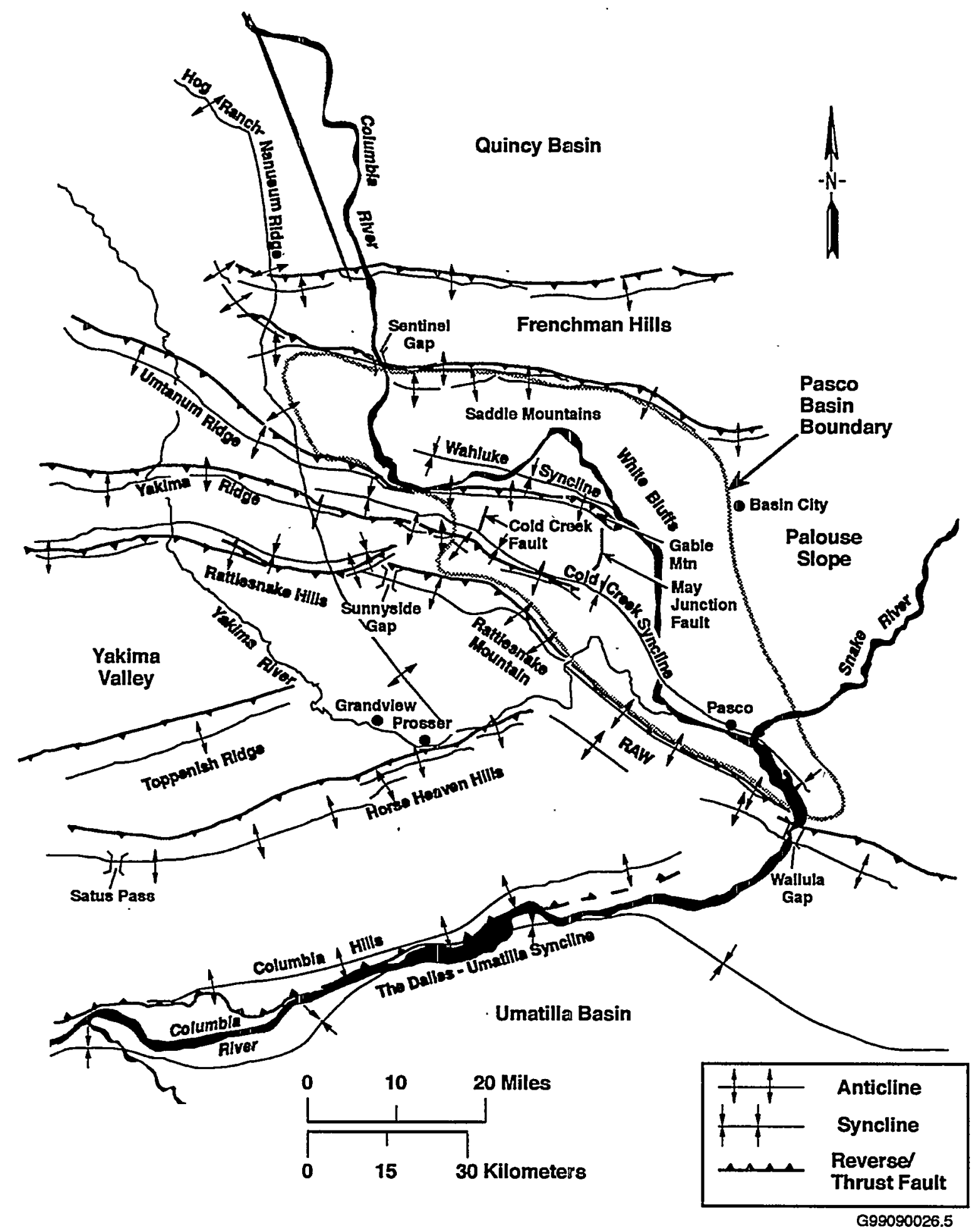

Figure 4.1. Structural and Tectonic Map of Columbia Basin Showing Major Seismic Source Structures 
Yakima Fold Belt $\quad$ Palouse Slope

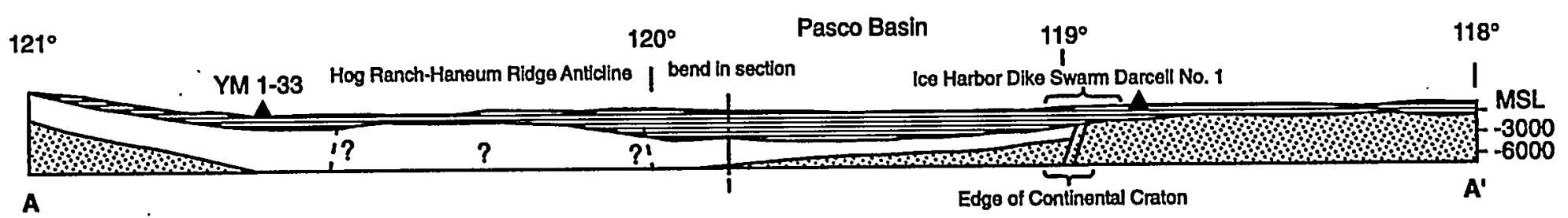

$\stackrel{\leftrightarrow}{\omega}$

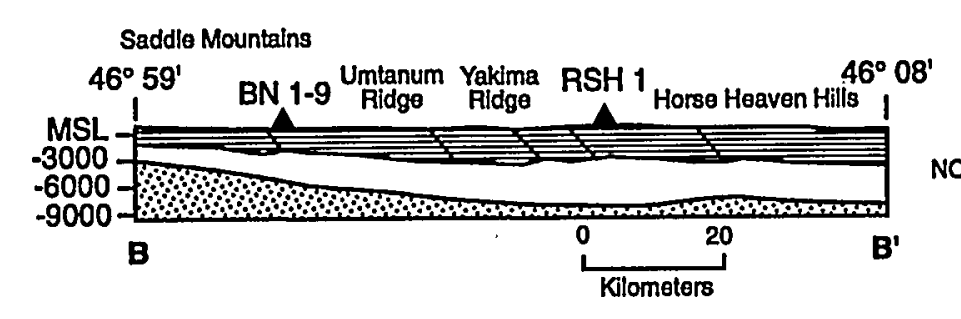

A Hydrocarbon exploration borehole
畾 Columbia River Basalt Group

ge of Continental Craton $-6000$

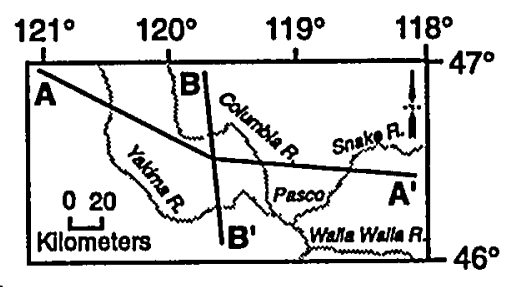

$\square$ Tertiary sediments

Basement rock

SP98020037.3

Figure 4.2. Geologic Cross Sections Through the Columbia Basin 
Table 4.1. Thicknesses of Stratigraphic Units in the Monitoring Area

\begin{tabular}{|l|l|l|l|l|}
\hline \multicolumn{1}{|c|}{ Stratigraphy } & \multicolumn{1}{|c|}{ North } & \multicolumn{1}{c|}{ South } & \multicolumn{1}{c|}{ East } & \multicolumn{1}{c|}{ West } \\
\hline \hline $\begin{array}{l}\text { Columbia River Basalt Group (includes } \\
\text { suprabasalt sediments) }\end{array}$ & $3.0 \mathrm{~km}$ & $4.5 \mathrm{~km}$ & $2.2 \mathrm{~km}$ & $4.2 \mathrm{~km}$ \\
\hline Pre-basalt Sediments & $3.0 \mathrm{~km}$ & $>4.5 \mathrm{~km}$ & 0 & $>6.0 \mathrm{~km}$ \\
\hline
\end{tabular}

The thickness of the basalt and the pre-basalt sediments varies as a result of different tectonic environments. The western edge of the North American craton (late Precambrian/Paleozoic continental margin and Precambrian craton) is located in the eastern portion of the monitored area. The stratigraphy on the craton consists of CRBG overlying crystalline basement; the crystalline basement is continental crustal rocks that underlie much of the western North America. The stratigraphy west of the craton consists of $4-5 \mathrm{~km}$ of CRBG overlying greater than $6 \mathrm{~km}$ of pre-basalt sediments. This in turn overlies accreted terranes of Mesozoic age. The area west of the craton was subsiding during the Eocene and Oligocene, accumulating great thickness of pre-CRBG sediments. Continued subsidence in this area during the Miocene resulted in thicker CRBG compared to that on the craton. Subsidence continues today but at a greatly reduced rate (Reidel et al. 1994).

\subsection{Depth of Earthquakes}

Since records have been kept, about $75 \%$ of the earthquakes at the Hanford Site have originated in the CRBG layer. The pre-basalt sediments have had about $7 \%$ of the events and the crystalline basement has had 18\%. The stratigraphic units for local earthquakes recorded for FY 1999 are listed in Table 4.2.

Table 4.2. Number of Local Earthquakes Occurring in Stratigraphic Units

\begin{tabular}{|l|c|c|c|c|c|}
\hline \multicolumn{1}{|c|}{ Unit } & First Quarter & Second Quarter & Third Quarter & Fourth Quarter & FY 1999 \\
\hline \hline Basalt & 7 & 11 & 11 & 9 & $38(53 \%)$ \\
\hline Pre-basalt Sediments & 0 & 0 & 4 & 2 & $6(8 \%)$ \\
\hline Crystalline Basement & 7 & 6 & 4 & 11 & $28(39 \%)$ \\
\hline Total & 14 & 17 & 19 & 22 & 72 \\
\hline
\end{tabular}

\subsection{Tectonic Pattern}

Studies have concluded that earthquakes can occur in the following six different tectonic environments (earthquake sources) at the Hanford Site (Geomatrix 1996).

- Reverse/thrust faults. Reverse/thrust faults in the CRBG associated with major anticlinal ridges such as Rattlesnake Mountain, Yakima Ridge, and Umtanum Ridge could produce some of the largest earthquakes. 
- Secondary faults. These are associated with the major anticlinal ridges.

- Swarm areas. Small geographic areas of unknown geologic structure produce clusters of events (swarms), usually in the CRBG in synclinal valleys. These clusters consist of a series of small shocks with no outstanding principal event. Swarms occur over a period of days or months and the events may number into the hundreds and then quit, only to start again at a later date. This differs from the sequence of foreshocks, mainshock, and trailing-off aftershocks that have the same epicenter or are associated with the same fault system. Three principal swarm areas are known at the Hanford Site. One is the Wooded Island Swarm Area along the Columbia River near the 300 Area. The second area, the Coyote Rapids Swarm Area, extends from the vicinity of the 100-K Area north-northeast along the Columbia River Horn to the vicinity of the $100-\mathrm{N}$ Area. The third major swarm area is along the Saddle Mountains on the northern boundary of the Hanford Site. Other earthquake swarm areas are present, but activity is less frequent.

- The entire Columbia Basin. The entire basin, including the Hanford Site, could produce a "floating" earthquake. A floating earthquake is one that, for seismic design purposes, can happen anywhere in a tectonic province and is not associated with any known geologic structure. It is classified as a random event by Seismic Monitoring for purposes of seismic design and vibratory ground motion studies.

- Basement source structures. Studies (Geomatrix 1996) suggest that major earthquakes can originate in tectonic structures in the crystalline basement. Because little is known about geologic structures in the crystalline basement beneath the Hanford Site, earthquakes cannot be directly tied to a mapped fault. Earthquakes occurring in the crystalline basement without known sources are treated as random events for seismic hazards analysis and seismic design.

- The Cascadia Subduction Zone. This source recently has been postulated to be capable of producing a magnitude 9 earthquake. Because this source is along the western boundary of Washington State and outside the HSN, the Cascadia Subduction Zone is not an earthquake source that is monitored at the Hanford Site, so subduction zone earthquakes are not reported here. Because any earthquake along the Cascadia Subduction zone can have a significant impact on the Hanford Site (Geomatrix 1996), the UW monitors and reports on this earthquake source for DOE. Ground motion from any moderate or larger Cascadia Subduction Zone earthquake is detected by seismometers in the HSN.

\subsection{Tectonic Activity}

The locations for earthquakes that occurred in FY 1999 are summarized in Tables 4.2 and 4.3. Earthquakes that occurred in the fourth quarter are described in the following section and a summary of all the earthquakes that occurred in FY 1999 follows. 
Table 4.3. Summary of Earthquake Locations

\begin{tabular}{|c|c|c|c|c|c|c|}
\hline & & $\begin{array}{l}\text { First } \\
\text { Quarter }\end{array}$ & $\begin{array}{l}\text { Second } \\
\text { Quarter }\end{array}$ & $\begin{array}{l}\text { Third } \\
\text { Quarter }\end{array}$ & $\begin{array}{l}\text { Fourth } \\
\text { Quarter }\end{array}$ & FY 1999 \\
\hline \multicolumn{2}{|c|}{$\begin{array}{l}\text { Major structures along anticlinal } \\
\text { Ridges }\end{array}$} & 1 & 2 & 0 & 1 & 4 \\
\hline \multirow{6}{*}{$\begin{array}{l}\text { Swarm } \\
\text { Areas }\end{array}$} & Saddle Mountains & 1 & 0 & 0 & 1 & 2 \\
\hline & Coyote Rapids & 0 & 7 & 2 & 2 & 11 \\
\hline & Wooded Island & 0 & 1 & 3 & 4 & 8 \\
\hline & Wahluke Slope & 6 & 0 & 0 & 0 & 6 \\
\hline & Horse Heaven Hills & $5^{(\mathrm{a})}$ & 0 & 6 & 1 & 12 \\
\hline & Benson Ranch & 0 & $1^{(\mathrm{b})}$ & $1^{(\mathrm{b})}$ & 6 & 8 \\
\hline \multicolumn{2}{|c|}{ Random Events } & $1^{(\mathrm{a})}$ & $6^{(\mathrm{b})}$ & $77^{(\mathrm{b})}$ & 7 & 21 \\
\hline
\end{tabular}

\subsubsection{Fourth Quarter of FY 1999}

The locations of all located earthquakes that occurred between July 1 and September 30, 1999 are shown on Figure 4.3.

\subsubsection{Major Anticlinal Ridges}

During the fourth quarter, we interpret one seismic event to have occurred on a major ridge. On July 24,1999 , a small $\left(0.6 \mathrm{M}_{c}\right)$, shallow earthquake occurred along the north side of the Horse Heaven Hills anticline near Prosser, Washington.

\subsubsection{Swarm Area Activity}

Fourteen earthquakes (64\%) occurred in swarm areas during the fourth quarter of FY 1999 (Table 4.3). Four earthquakes occurred in the Wooded Island swarm area, two occurred in the Coyote Rapids swarm area, one in the Saddle Mountain swarm area, one in the Horse Heaven Hills swarm area, and six in the Benson Ranch swarm area.

\subsubsection{Wooded Island Swarm Area}

Three small $\left(<1 \mathrm{M}_{\mathrm{c}}\right)$ earthquakes occurred near Johnson Island during the month of August. A fourth earthquake occurred eight miles east of the main swarm on September 1, 1999. All four events were in the CRBG. 


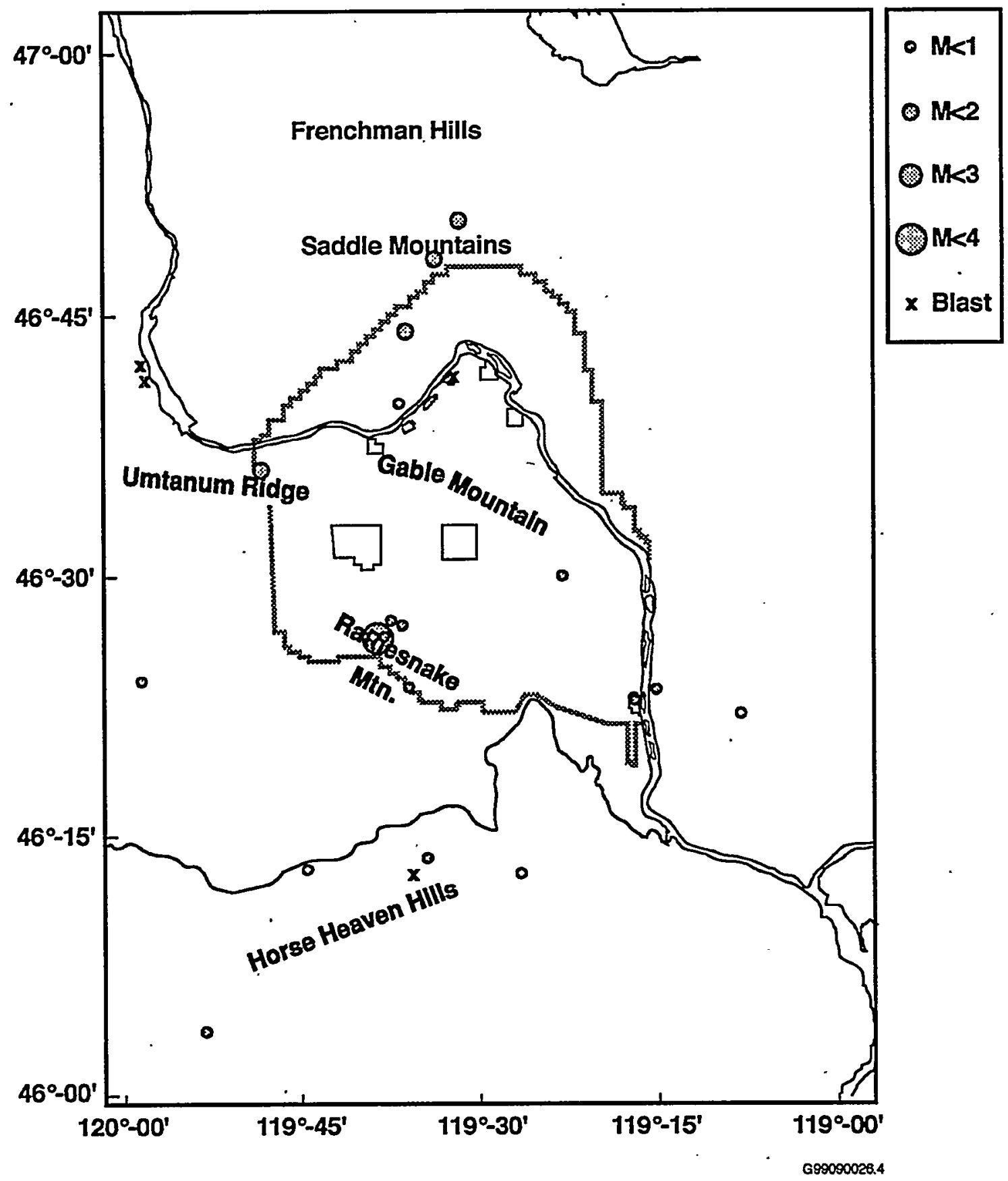

Figure 4.3. Locations of All Events Between July 1, 1999 and September 21, 1999 (Coda Length Magnitude $\left[\mathrm{M}_{\mathrm{c}}\right]$ scale is shown at the side of the map) 


\subsubsection{Coyote Rapids Swarm Area}

Two events occurred in the Coyote Rapids swarm area during the fourth quarter of FY 1999. One event $\left(0.1 \mathrm{M}_{\mathrm{c}}\right)$ occurred on July $30,1999,3 \mathrm{~km}$ north of 100-K Area. A second event occurred on August 18, 1999, $11 \mathrm{~km}$ northeast of $100-\mathrm{K}$ Area. Both earthquakes occurred in the CRBG.

\subsubsection{Saddle Mountains Swarm Area}

One (1.4 $\mathrm{M}_{\mathrm{c}}$ ) earthquake occurred in the Saddle Mountains swarm area on September 17, 1999. The event was $3 \mathrm{~km}$ north of the Saddle Mountains anticline near the east end of the Smyrna Bench segment and occurred in the CRBG.

\subsubsection{Horse Heaven Hills Swarm Area.}

A small $(0.3 \mathrm{Mc})$ earthquake occurred on September 6, 1999 along the south limb of the Horse Heaven Hills anticline. This event occurred in the CRBG and was near earthquakes that occurred during the third quarter.

\subsubsection{Benson Ranch Swarm Area}

Six earthquakes occurred in the Benson Ranch swarm area during September. The $\mathrm{M}_{\mathrm{c}} 3.0$ earthquake that occurred on September 19 was the largest event to occur in the Hanford monitoring area this fiscal year. Its hypocenter depth indicates that it occurred in the crystalline basement. A small event $\left(\mathbf{M}_{\mathrm{c}} \mathbf{0 . 1}\right)$ occurred a week earlier on September 11, and three small events occurred in the 22 hours after the magnitude $3\left(M_{c} 0.4,1.4\right.$, and -0.1). An additional small earthquake occurred over a week later on September $27\left(\mathrm{M}_{\mathrm{c}} 1.0\right)$. This sequence has mixed characteristics: the three small events shortly after the $\mathrm{M}_{\mathrm{c}} 3$ event would be considered aftershocks, considering the relatively large size difference from the "mainshock." The events about one week before and after seem sufficiently separate in time to be similar to a swarm sequence. Note that there were earlier small earthquakes located near this sequence on August 26 (approximately $5 \mathrm{~km}$ south), and in previous quarters (see Figure 4.4) on January 7 and April 27, 1999. There was also another earthquake located there on October 27, 1999 in the quarter following the current reporting period.

\subsubsection{Random or Floating Events}

There were seven events (32\%) classified as random events this quarter because they did not occur in known earthquake swarm areas or along known geologic structures. One event occurred in the CRBG, two events were in the prebasalt sediments and four events were in the crystalline basement. No faults or folds have been identified below the basalt so events in the prebasalt sediments and crystalline basement are classified as random events.

Two random events occurred in the crystalline basement near Prosser, Washington during the fourth quarter. The first event on July 6, 1999 was small $(0.4 \mathrm{Mc})$ and occurred near the "bend" in the Horse 


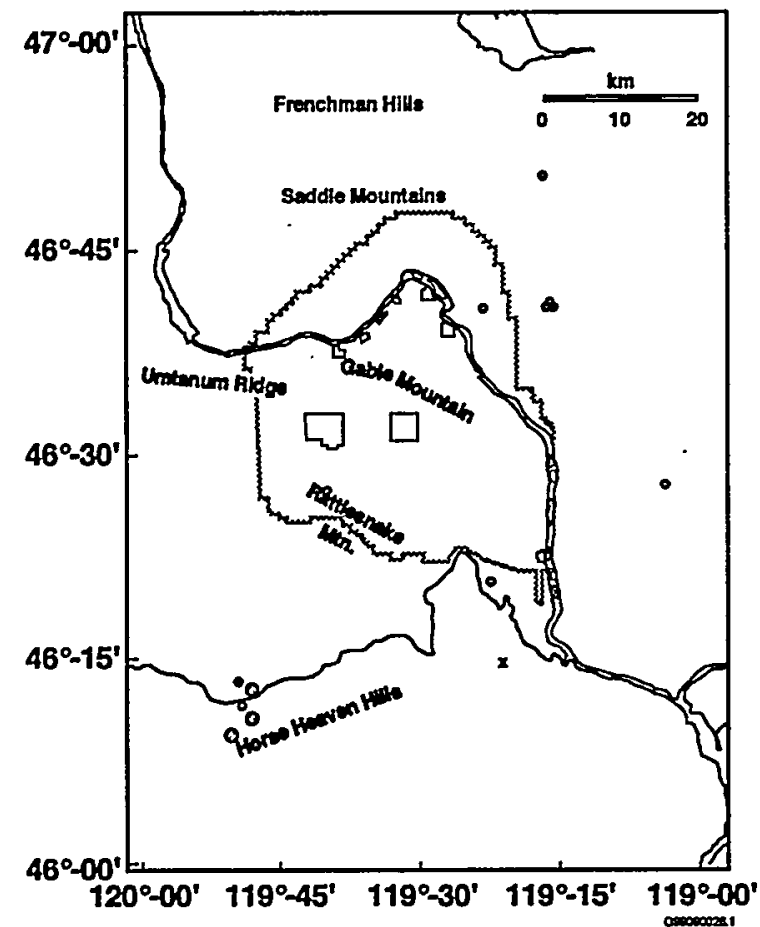

October 1, 1998 - December 31, 1998

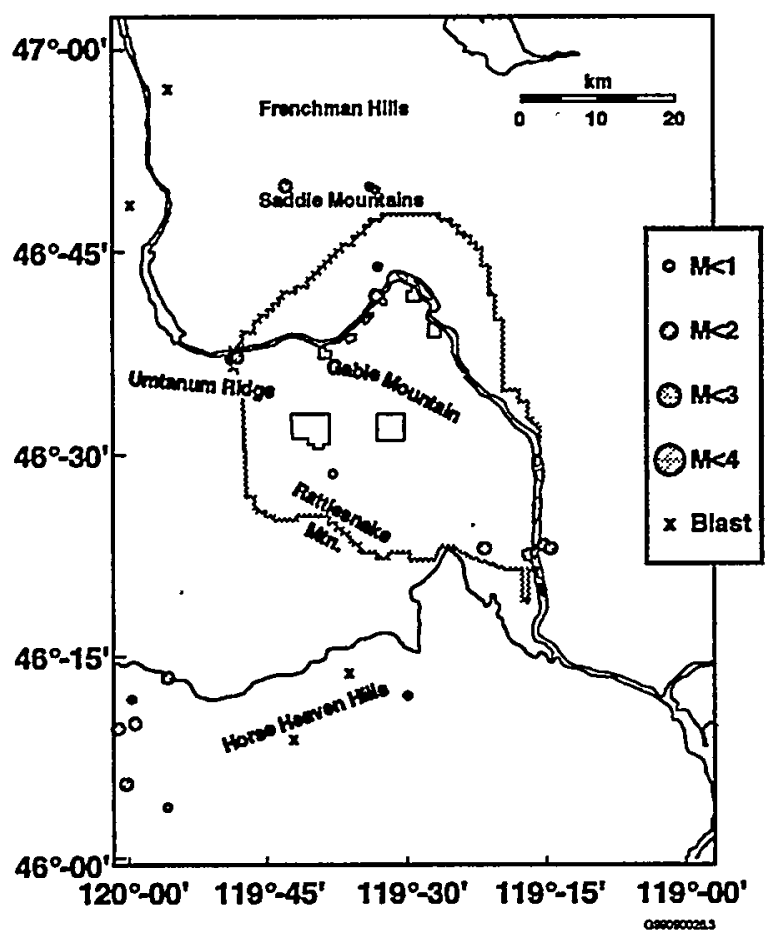

April 1, 1999 - June 30, 1999

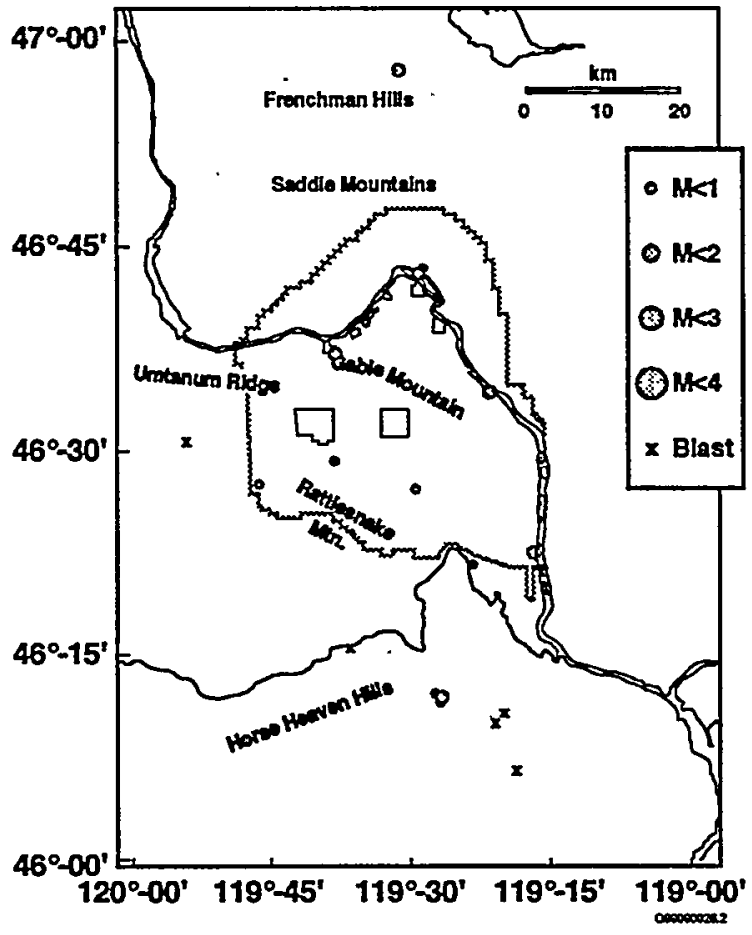

January 1, 1999 - March 31, 1999

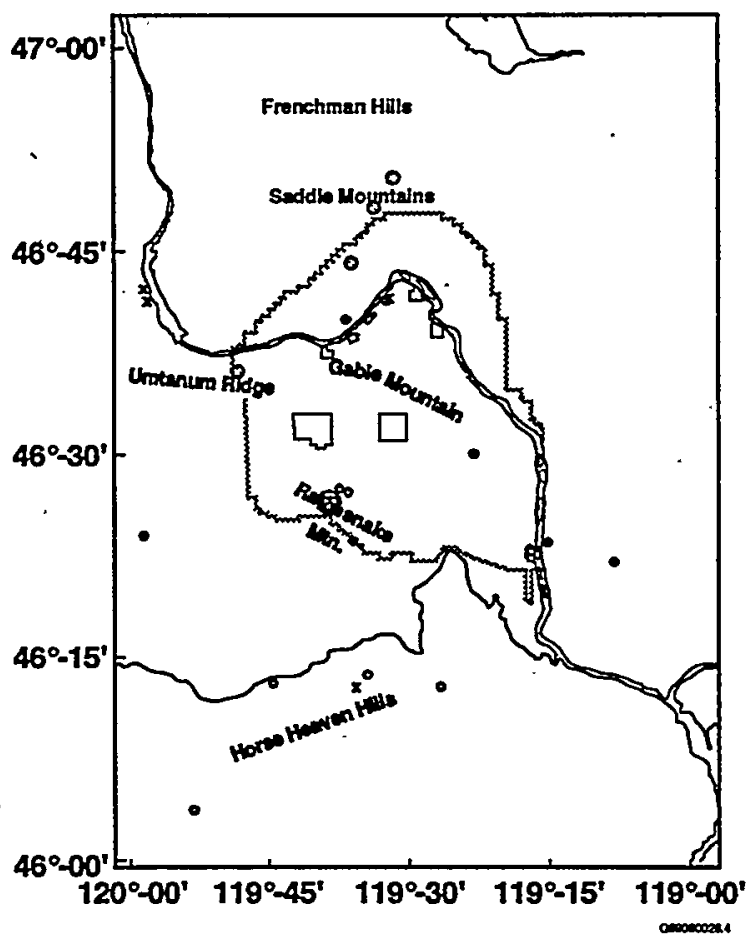

July 1, 1999 - September 21, 1999

Figure 4.4. Locations of all Events that Occurred Between October 1, 1998 and September 21, 1999 Shown by Quarter (Coda Length Magnitude $\left(M_{c}\right)$ scale is shown at the side of the map) 
Heaven Hills anticline. The second event on September 19 was also small (near $0 \mathrm{Mc}$ ) and occurred on the south limb of the Rattlesnake Hills north of Prosser, Washington.

On July 24,1999 , a $1.3 \mathrm{M}_{\mathrm{c}}$ event occurred in the crystalline basement the Saddle Mountains near Wahatis Peak. Two previous events occurred there during FY 1999.

One small $\left(0.3 \mathrm{M}_{\mathrm{c}}\right)$ event occurred on August 19,1999 in the Wye Barricade depression of the Cold Creek syncline. The event occurred in the CRBG. This event was about $3 \mathrm{~km}$ east of the May Junction fault.

On August 26, 1999, a small $\left(0.4 \mathrm{M}_{\mathrm{c}}\right)$ earthquake occurred on the Arid Lands Ecology Reserve below Rattlesnake Mountain. This event occurred in the crystalline basement.

A $1.2 \mathrm{M}_{\mathrm{c}}$ event occurred on August 29, 1999 on the western boundary of the Hanford Site near Umtanum Ridge. Two events occurred; the first event occurred there during the third quarter. All events were in the sediments underlying the CRBG.

One small $\left(0.3 \mathrm{M}_{\mathrm{c}}\right)$ event occurred near Webber Canyon south of Kennewick, Washington on September 5, 1999 in the sediments underlying the CRBG along the Horse Heaven Hills. Four other events occurred near this location during FY 1999.

\subsection{Annual Report for FY 1999}

Seventy-two local events occurred between October 1, 1998 and September 30, 1999. The locations of all located earthquakes are shown on Figures 4.4 and 4.5 .

\subsubsection{Major Anticlinal Ridges}

Between October 1, 1998 and September 30, 1999, four earthquakes (6\%) occurred on major anticlinal ridges. During the first and second quarters, two small $\left(0.1 \mathrm{M}_{\mathrm{c}}\right)$ earthquakes occurred on the Horn Rapids anticline. During the second quarter, a small $\left(1.0 \mathrm{M}_{\mathrm{c}}\right)$ earthquake occurred on the north flank of the Frenchman Hills anticline. During the fourth quarter, a small $\left(0.6 \mathrm{M}_{c}\right)$ earthquake occurred on the Horse Heaven Hills near Prosser, Washington. All earthquakes were small and showed no apparent pattern of activity.

\subsubsection{Swarm Area Activity}

Between October 1, 1998 and September 30, 1999, 47 earthquakes (65\%) occurred in swarm areas (Table 4.3). Two earthquakes occurred in the Saddle Mountains swarm area, 11 occurred in the Coyote Rapids swarm area (3 at 100-K Area), 6 occurred in the Wahluke Slope swarm area, 8 occurred in the Wooded Island swarm area, 12 occurred in a new swarm near Prosser, Washington and the Horse Heaven Hills, and 8 occurred near Benson Ranch in the Cold Creek syncline. 


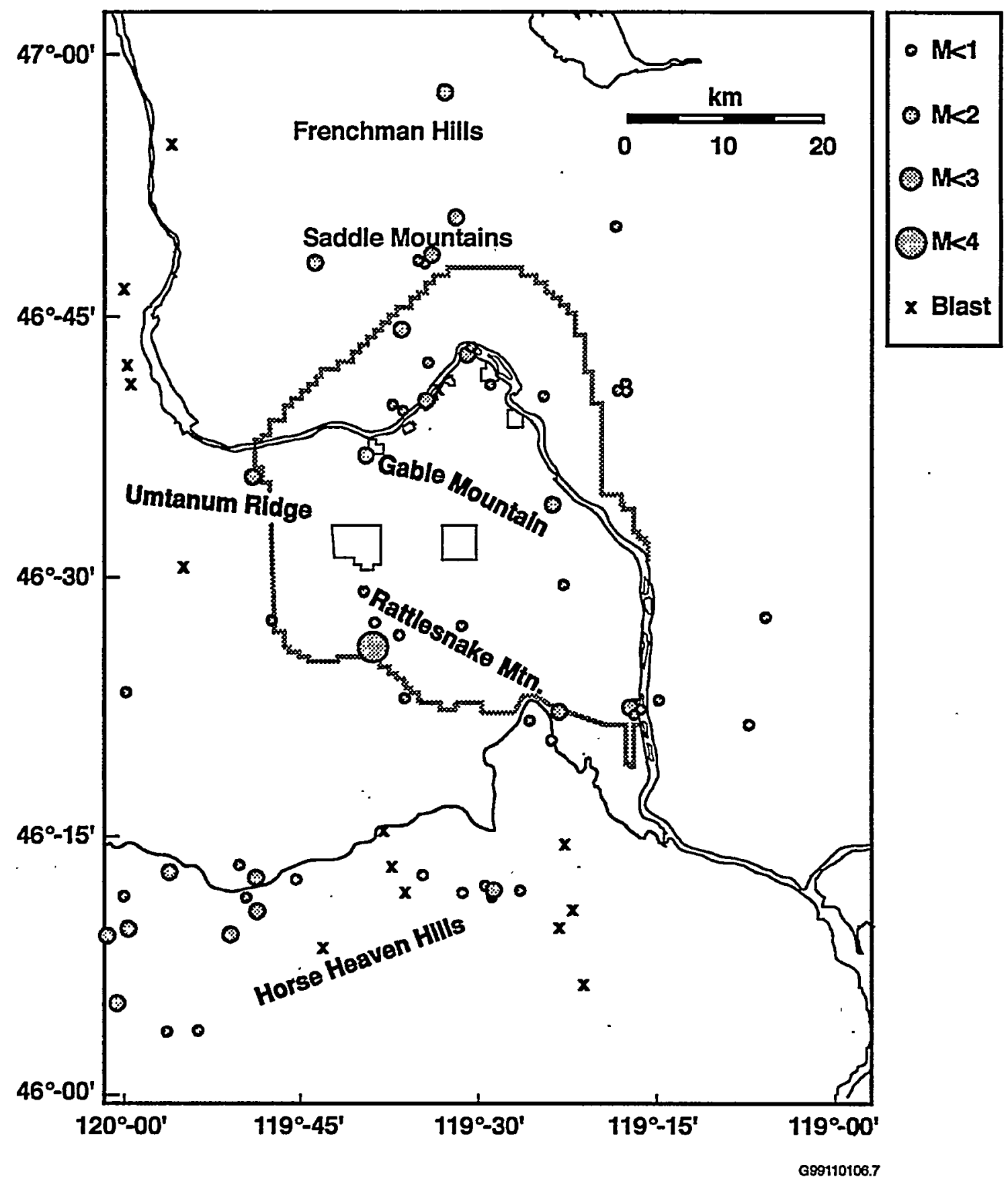

Figure 4.5. Locations of all Events Recorded During FY 1999 
All earthquakes were small and almost all occurred in the CRBG. Two notable exceptions are: 1) the Benson Ranch swarm area which occurred during the fourth quarter, that included the largest event located this year, $M_{c} 3.0$, and 2) the Horse Heaven Hills swarm area (not previously classified as a swarm area), that had a maximum magnitude earthquake of $\mathrm{M}_{\mathrm{c}}$ 1.7. The Benson Ranch earthquakes occurred in the crystalline basement and they had mixed characteristics. They displayed both "mainshock" and "aftershocks" with a relatively large difference in magnitude between the two, yet they were sufficiently separate in time to be similar to a swarm sequence. The Horse Heaven Hills swarm occurred deep in the crystalline basement initially and then became shallower later. The Horse Heaven Hills events are less well constrained because of the absence of monitoring sites west of the swarm area.

The other swarm areas appeared to be similar to past activity. They occurred as a series of small shocks with no outstanding principal event over a period of days or months. They then quit, only to start again at a later date.

\subsubsection{Random or Floating Events}

There were 21 events (29\%) classified as random between October 1, 1998 and September 30, 1999 because they did not occur in a known earthquake swarm area or along a known geologic structure. Three events occurred in the CRBG, eight events were in the sediments underlying the basalt, and nine events were in the crystalline basement. No faults or folds have been identified below the basalt so events that deep are classified as random events.

Of the random events, several clusters of events appeared during the year:

- Five earthquakes occurred near Webber Canyon and all were located in the prebasalt sediments.

- Three earthquakes occurred on the south flank of Umtanum Ridge on the west side of the Hanford Site and all were in prebasalt sediments. In previous years, several earthquakes have occurred here.

- Three earthquakes occurred near Wahatis peak in the Saddle Mountains. All were located in the crystalline basement. 


\subsection{Strong Motion Accelerometer Operations}

The Hanford SMA network was restarted November 20, 1998 after a one year hiatus. During the 1 month of operating during the first quarter and the remainder of the fiscal year, there were no earthquake triggers. The SMA network had several triggers resulting from noise. The number of triggers resulting from noise and normal human activity is being monitored to determine the optimal settings for the triggering system. Our objective is to obtain an optimum balance between having minimal triggers caused by noise and detection of the smallest possible earthquake. 


\subsection{Capabilities in the Event of a Significant Earthquake}

The SMA network was designed to provide ground motion in areas at the Hanford Site that have high densities of people and/or have hazardous facilities. This section summarizes the capabilities of the Seismic Monitoring Team in the event of an earthquake at Hanford.

\subsection{Use of the SMA Network in the Event of an Earthquake}

Historically, only a few facilities at the Hanford Site had instruments to provide data on peak ground accelerations or any type of ground motion. The present SMA instruments were located so that if an earthquake occurred, ground motion data would be readily available to assess the damage at the 100-K Area, the 200 East and West Areas, the 300 and 400 Area facilities, which have the greatest concentration of people, and all the hazardous materials.

Many facilities at the Hanford Site have undergone various degrees of seismic analysis either during design or during re-qualification. Although the seismic design of a building may be known, when an earthquake is felt, a determination must be made as to the extent of damage before it can be reoccupied and the systems restarted. A felt earthquake may not cause any damage to a building but without adequate characterization of the ground motion, initial determination of damage may be impossible.

In the event of an earthquake, building managers, emergency directors, and engineers can obtain ground motion data recorded by the SMA network from the Seismic Monitoring Team in the Sigma V Building. If a SMA is triggered, the Seismic Monitoring Team will download events that were recorded and determine the peak ground accelerations and the spectral response curves. This information can then be used by the facility engineers to determine if the ground motion exceeded, is equal to, or is less than the building design. This, together with assessments from trained engineers, allows the facility manager to make a rapid and cost effective determination on whether a building is safe to reoccupy or should be not be used until it has been inspected in more detail. Buildings that have designs exceeding the recorded ground motion could be put back into service very quickly; buildings with designs that are very close to or less than measured ground motion could be given priority for onsite damage inspections. 


\subsection{References}

Campbell, N. P. 1989. "Structural and stratigraphic interpretation of rocks under the Yakima fold belt, Columbia Basin, based on recent surface mapping and well data." In S. P. Reidel and P. R. Hooper (eds.), Volcanism and Tectonism in the Columbia River Flood-Basalt Province Geological Society of America Special Paper 239, pp. 209-222.

Crosson, R. S. 1972. Small Earthquakes, Structure and Tectonics of the Puget Sound Region. Bulletin of the Seismological Society of America, 62(5):1133-1171.

DOE. 1988. Site Characterization Plan for the Reference Location, Hanford, Washington-Consultation Draft. Report DOE/RW-0164, Vol. 1, U.S. Department of Energy, Washington, D.C.

Fenneman, N. M. 1931. Physiography of western United States. McGraw-Hill, 534 p.

Geomatrix. 1996. Probabilistic Seismic Hazard Analysis, DOE Hanford Site, Washington. WHC-SDW236A-TI-002, Rev. 1, Westinghouse Hanford Company, Richland, Washịgton.

Moore, C., and S. P. Reidel. 1996. Hanford Site Seismic Monitoring Instrumentation Plan. WHC-SDGN-ER-30036, Westinghouse Hanford Company, Richland, Washington.

Reidel, S. P., and P. R. Hooper (eds.). 1989. Volcanism and Tectonism in the Columbia River FloodBasalt Province Geological Society of America Special Paper 239, 386 p.

Reidel, S. P., N. P. Campbell, K. R. Fecht, and K. A. Lindsey. 1994. "Late Cenozoic Structure and Stratigraphy of South-Central Washington." In E. Cheney and R. Lasmanis (eds.), Regional Geology of Washington State, Washington Division of Geology and Earth Resources Bulletin 80, pp. 159-180, Olympia, Washington.

Reidel, S. P., K. R. Fecht, M. C. Hagood, and T. L. Tolan. 1989. "Geologic Development of the Central Columbia Plateau." In S. P. Reidel and P. R. Hooper (eds.), Volcanism and Tectonism in the Columbia River Flood-Basalt Province Geological Society of America Special Paper 239, pp. 247-264.

Richter, C. F. 1958. Elementary Seismology, W. H. Freeman and Company, p. 768.

Rohay, A. C., D. W. Glover, and S. D. Malone. 1985. Time-Term Analysis of Upper Crustal Structure in the Columbia Basin, Washington. RHO-BW-SA-435 P, Rockwell Hanford Operations, Richland, Washington. 


\section{Distribution}

No. of

Copies

\section{OFFSITE}

Consolidated Information Center

Washington State University - Tri-Cities

100 Sprout Road

Richland, WA 99352-1643

J. Litehiser

Bechtel National, Inc.

P.O. Box 193965

San Francisco, CA 94119-3965

3 Oregon Department of Geology and Mineral Industries

Suite 965, 800 NE Orgeon Street \#28

Portland, OR 97232

ATTN: J. Beaulieu

Library

I. Madin

S. Sobczyk

Nez Perce Tribe

P.O. Box 365

Lapwai, ID 83540

M. Stickney

Montana Tech University

Earthquake Studies Office

Butte, MT 59701

A. Tallman

1940 Quail Court

West Richland, WA 99353
No. of

Copies

5 University of Washington

Geophysic Program

P.O. Box 351650

Seattle, WA 98195-1650

ATTN: R. Crosson

R. Ludwin

S. Malone

A. Qamar

R. Steele

2 U.S. Geological Survey

University of Washington

P.O. Box 351650

Seattle, WA 98195

ATTN: C. Weaver

T. Yelin

5 Washington Division of Geology and Earth Resources

P.O. Box 47007

Olympia,-WA 98504-7007

ATTN: R. LasManis

C. Manson

S. Palmer

J. Schuster

T. Walsh

Washington State University

Department of Geology

P.O. Box 643420

Pullman, WA 99164-3520

J. Zollweg

Boise State University

Department of Geosciences

Boise, ID 83725

Distr.1 
No. of

Copies

ONSITE

6 DOE Richland Operations Office

M. J. Furman

R. D. Hildebrand

J. E. Mecca

M. R. Moreno

K. M. Thompson

J. L. Tokarz-Hames

2 Bechtel Hanford, Inc.

K. R. Fecht

P. J. Mackey

B\&W Hanford Company

D. A. Conners

2 Duke Engineering \& Services, Inc.

R. Whitehurst

R3-86

M. K. Mahaffey

DynCorp Tri-Cities Services, Inc.

T. P. Morales

A3-05

2 Fluor Daniel Hanford, Inc.

J. T. Curtis

S. M. Faulk

$\mathrm{H} 0-12$

$\mathrm{H} 0-12$

R3-79

A5-55

$\mathrm{H} 0-12$

A5-55

$\mathrm{H} 0-02$

B3-15

T5-11

R3-86
No. of

Copies

Fluor Daniel Northwest, Inc.

F. M. Mann

$\mathrm{H} 0-22$

M. I. Wood

H6-06

M. T. York

T3-01

15 Pacific Northwest National Laboratory

M. V. Berriochoa

K9-56

D. C. Hartshorn

K6-81

G. R. Holdren

K6-81

D. G. Horton

K6-96

S. J. Kowall

K8-12

S. P. Reidel

K6-81

A. C. Rohay

K6-81

R. M. Smith

K6-96

Information Release Office (7) 